\title{
THE MAUSOLEUM ARCHITECTURAL PROJECT: REINTERPRETING PALENQUE'S TEMPLE OF THE INSCRIPTIONS THROUGH 3D DATA-DRIVEN ARCHITECTURAL ANALYSIS
}

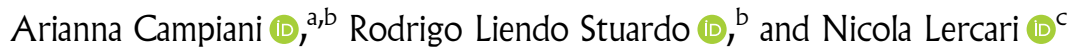 \\ aMarie Skłodowska Curie fellow, Department of Ancient World Studies, University of Rome-Sapienza, Piazzale Aldo Moro 8, 00185 \\ Roma, Italy

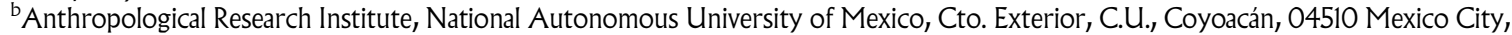 \\ Mexico \\ 'Department of Anthropology and Heritage Studies, University of California, 5200 North Lake Road, Merced, California 95343
}

\begin{abstract}
The Temple of the Inscriptions at Palenque, Mexico, is an outstanding example of Classic Maya architecture erected in the seventh century as the funerary building for ruler K'inich Janab Pakal. For decades, scholars have speculated on its construction sequence and the potential existence of hidden rooms on either side of Pakal's mortuary chamber. This article aims to advance understanding of the Temple's architectural context in light of new 3D data. After reviewing the application of drone-based photogrammetry and terrestrial Light Detection and Ranging in the Maya area, we argue that these techniques are capable of enhancing the architectural analysis of the Temple of the Inscriptions and showing that this structure was part of a larger architectural project, encompassing the adjacent Temple XIII, and the connecting stepped building platform. Our findings demonstrate that the basal platforms for the Temple of the Inscriptions and Temple XIII were erected contemporaneously and that the design of their mortuary chambers follows a tripartite layout we identified in Palenque's elite funerary architecture and associated mortuary practices. We conclude that these three buildings were part of a mausoleum architectural project, the construction of which was initiated by Pakal to reshape Palenque's site-core and enshrine the ruling family's power and ancestors.
\end{abstract}

\section{INTRODUCTION}

Archaeologists and architects focusing on ancient Mesoamerica have long been fascinated by the ingenious architectural program that produced the Temple of the Inscriptions at the Classic Maya site of Palenque, Mexico (Figure 1). For decades, scholars have speculated on its construction sequence and the existence of hidden rooms beneath the Temple. These rooms would be adjacent to the iconic funerary chamber where Mexican archaeologist Ruz Lhuillier (2013) retrieved the remains of Palenque's ruler K'inich Janab Pakal in 1952.

Building upon the performing "datafication" approach by Richards-Rissetto and Landau (2019), this study went beyond the $3 \mathrm{D}$ documentation of the Temple of the Inscriptions and integrated multiple levels of archaeological information to find new answers on its construction. Our approach is significant as it combines Palenque's archaeological record and legacy 2D architectural drawings with new 3D photogrammetric and terrestrial Light Detection and Ranging (LiDAR) data to produce new interpretations of the Temple's architectural context.

E-mail correspondence to: arianna.campiani@uniroma1.it
We argue that the Temple of the Inscriptions was part of a larger mausoleum architectural project planned by Pakal in the seventh century. We concur that this architectural program also involved the adjacent Temple XIII, the burial place for Pakal's consort ruler Ix Tz'akbu Ajaw, the so-called "Red Queen" (González Cruz 2011; Tiesler et al. 2004), and the stepped platform building connecting the two temples. We also argue that the latter structure was utilized during the construction of the basal platforms of the temples as an entryway into the funerary chambers to perform post mortem rituals.

In the section The Buildings of The Mausoleum Architectural Project, we described all the buildings that comprise Pakal's mausoleum architectural project. In the following section, we reviewed the prior application of the metric surveying and remote sensing methods employed in this study in the Maya area, specifically Terrestrial LiDAR, also known as Terrestrial Laser Scanning (TLS), and close-range photogrammetry, or Structure from Motion (SfM; Garrison et al. 2016; Golden et al. 2020; Merlo et al. 2012; Murtha et al. 2019; Tokovinine and Estrada-Belli 2017).

We analyze the mausoleum architectural project integrating new geospatial and 3D data collected at Palenque in 2018 with its archaeological record and legacy drawings (Figure 2; Lercari et al. 2018). This approach allowed us to observe new spatial correlations 


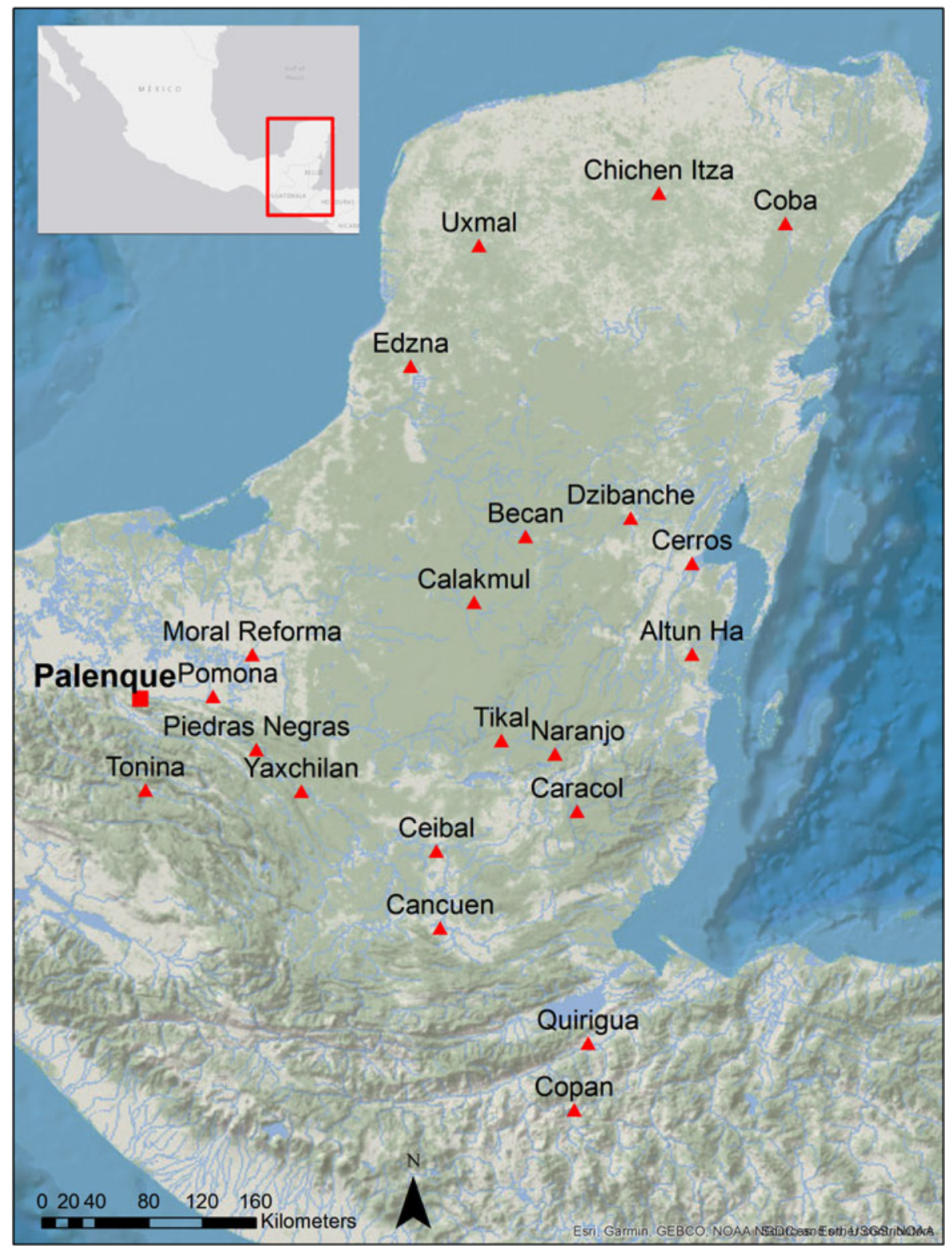

Figure 1. The ancient Maya City of Palenque (red square) and relevant contemporary Classic sites (red triangles) in the Maya Area. Map by Campiani.

in the building's architectural levels and their substructures. To further explain these correspondences, we have carefully analyzed published literature on Palenque's mortuary practices and the associated elite funerary architecture to propose a new interpretation of the funerary chamber of the Temple of the Inscriptions (González Cruz 2011; González Cruz and Balcells González 2015; Greene Robertson 2000; Ruz Lhuillier 2005; Schele 1986; Scherer 2012).

This enhanced architectural analysis allowed us to overcome the lack of primary excavation data regarding potential hidden spaces on either side of Pakal's funerary chamber. Based on our findings, we hypothesize that, similar to Temple XX and Temple XIII, the Temple of the Inscription's substructure also follows a tripartite layout consisting of three parallel chambers oriented north-south characterized by corbelled roofs. These parallelisms support our hypothesis that the temples' basal platforms were erected contemporaneously. Our results confirm that the Temple of the Inscriptions,
Temple XIII, and the stepped platform building connecting them were part of a single monumental architectural project planned and initiated by Pakal while still alive.

\section{THE BUILDINGS OF THE MAUSOLEUM ARCHITECTURAL PROJECT}

The southwest end of Palenque's site-core is characterized by a series of aligned temples abutting against the Sierra de Chiapas (Figure 3). These include the Temple of the Inscriptions, Temple XIII, the stepped platform building lying between them, Temple XII-A, and Temple XII. Each of these constructions housed a tomb beneath its basal platform (López Jiménez 2001:128), excluding the stepped platform buildings between the Temple of the Inscriptions and Temple XIII and Temple XII-A (Figure 4). 


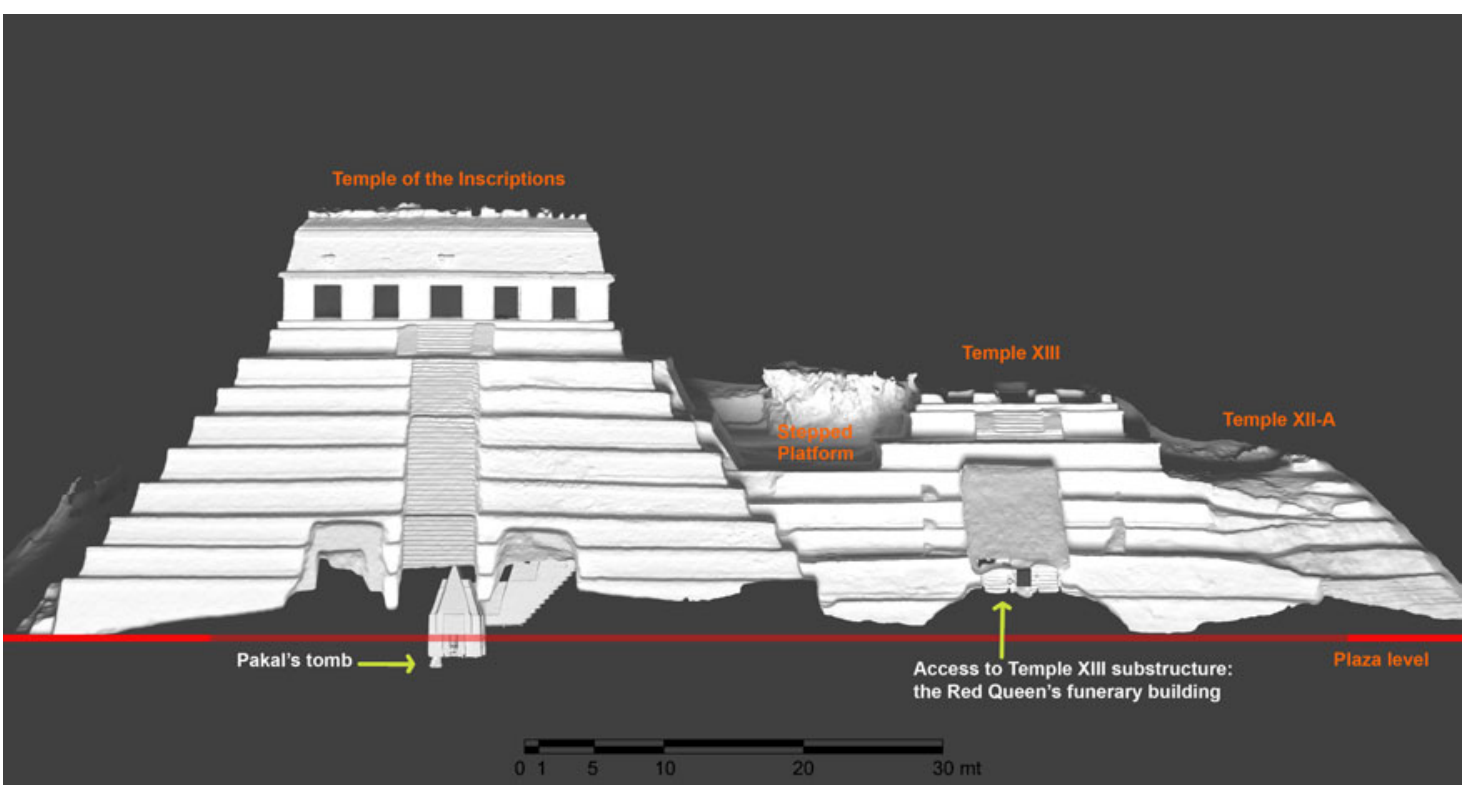

Figure 2. 3D rendering of the Temple of the Inscriptions, Temple XIII, and the stepped platform building, showing the location of their substructures. Image by Campiani and Lercari.

The Temple of the Inscriptions

As the easternmost structure, the Temple of the Inscriptions is the most prominent and well-known funerary building within Pakal's mausoleum architectural project. Named after the hieroglyphic tablets found in its front and rear rooms, the Temple is supported by a rectangular, two-stepped platform sitting on top of a truncated pyramid. A north-facing façade characterizes the Temple, with five doorways separated by large piers decorated with stucco reliefs and a central stairway with large sculptured alfardas, or ramps (Andrews 1978:99).

The interior consists of two, parallel, gallery-like rooms oriented east-west, where the outer gallery is longer than similar structures

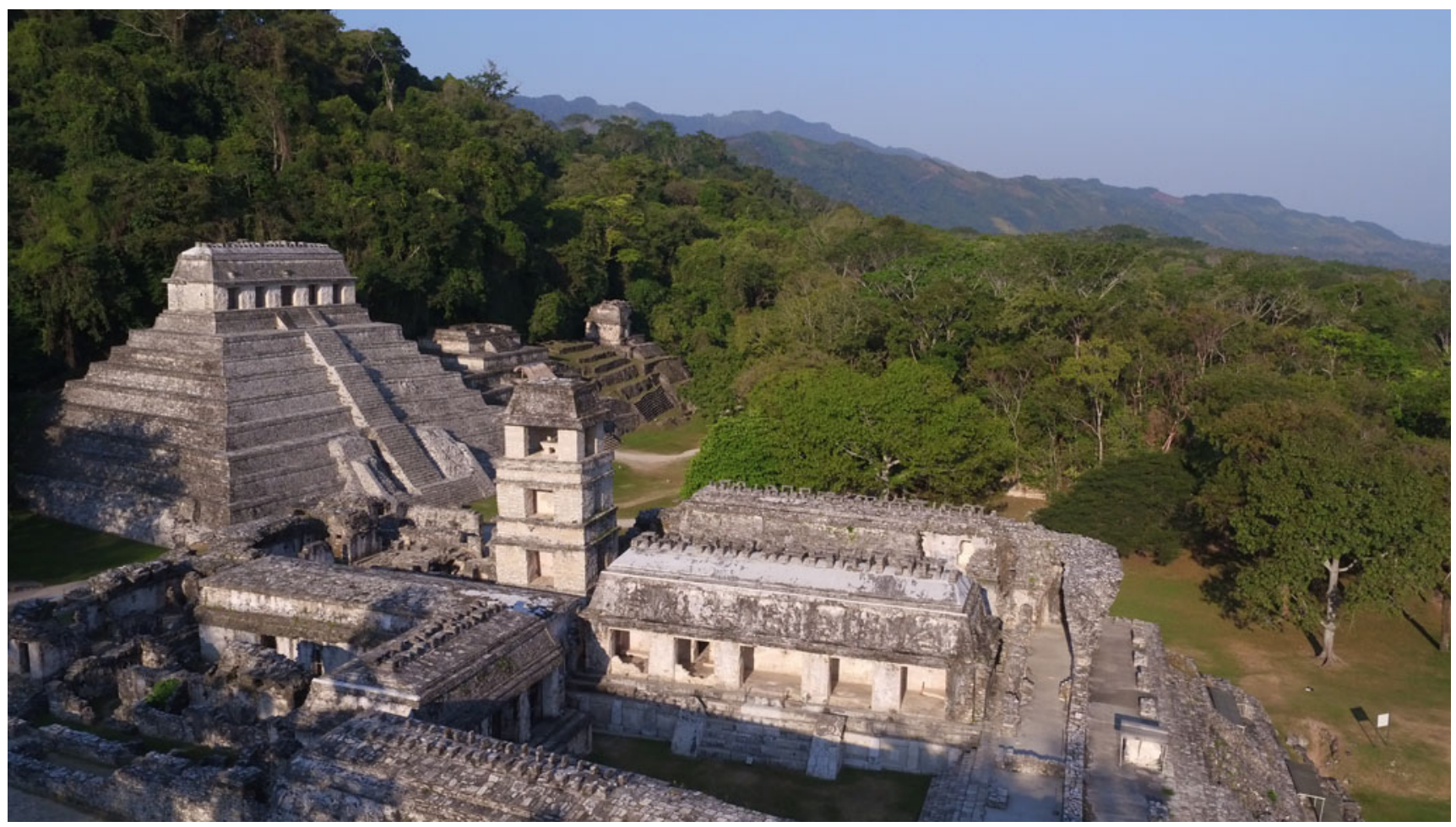

Figure 3. The Palace (foreground) and the buildings of Pakal's mausoleum architectural project (background) are seen in a low-altitude aerial photo, abutting against the Sierra de Chiapas. Photograph courtesy of Lercari. 


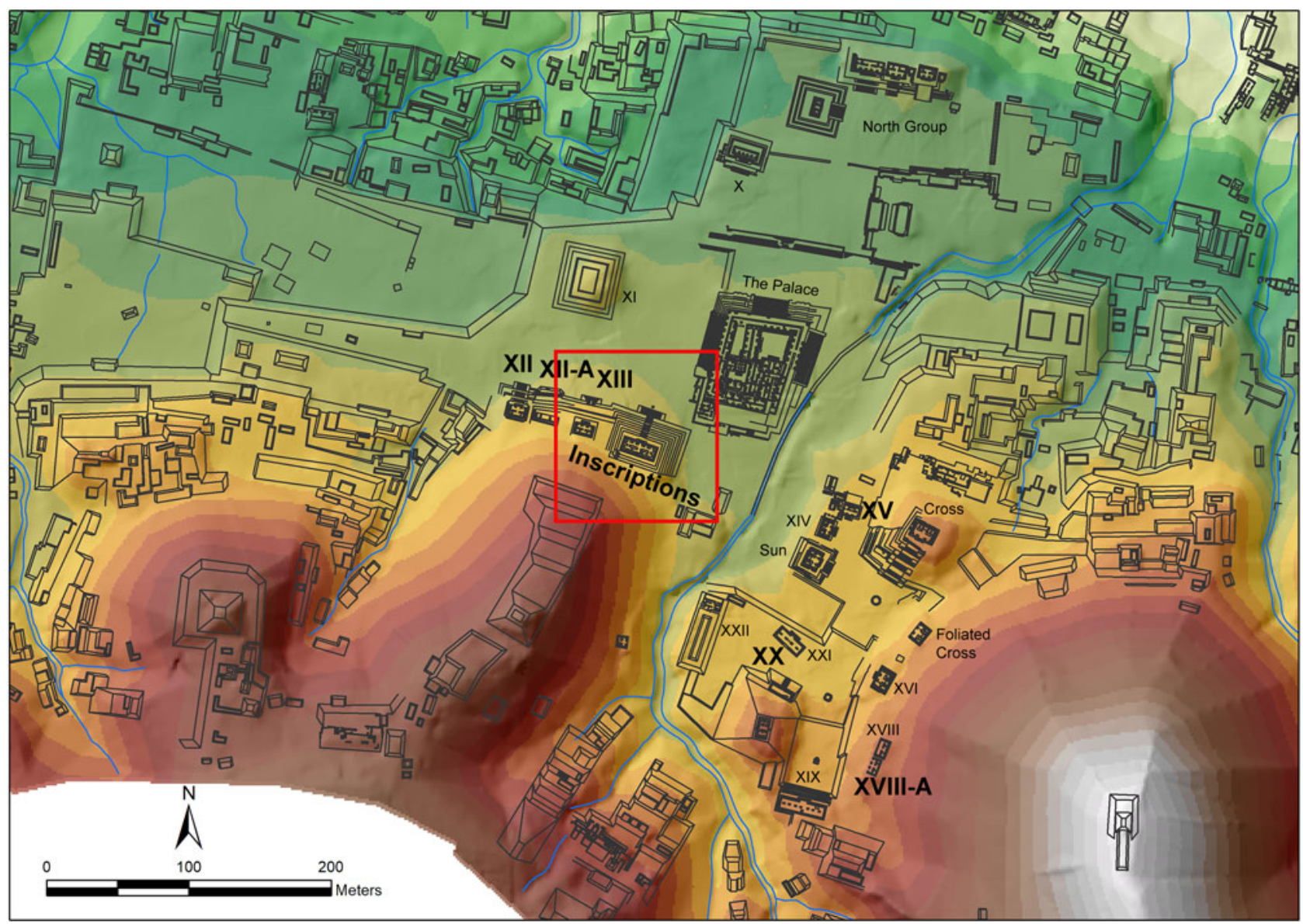

Figure 4. Palenque's site-core is seen on this map. The buildings mentioned in the text are labeled in bold font. The red square encompasses the buildings of the mausoleum architectural project. Image by Campiani, digital elevation model courtesy of Javier López Mejía, modified after Barnhart (2001).

documented at other temples at Palenque (Andrews 1978:107). The rear gallery, whose floor is $15 \mathrm{~cm}$ higher than the outer gallery, comprises three independent rooms of different sizes, among which the central one is the largest. From this room, an aperture in the floor covered by a removable monolithic slab gives access to a two-ramp stairway that descends from the Temple to Pakal's burial chamber. This architectural layout allowed the ancient Maya to perform acts of ancestor veneration until the descending shaft was intentionally filled with rubble in antiquity (Scherer 2012:246).

From 1949 to 1958, Ruz Lhuillier excavated the Temple of the Inscriptions. After four field seasons, he uncovered the stairway leading to Pakal's burial chamber (Ruz Lhuillier 2013). The tomb was first accessed from the stairway's end but was later shut down, and the last steps that led to that initial access were covered by a floor at a higher level, creating a corridor. At the end of the corridor, an elevated platform gives access into the chamber through a triangular door imperfectly sealed by a triangular slab (Ruz Lhuillier 2013:67). Four steps descend to an elevated landing composed of a huge slab leaning against the sarcophagus, filling the entire north-south oriented room. The chamber's soffit is remarkably corbelled by two consecutive straight vaults crossed by massive stone vault-beams (Marken 2007; Schele 1986). The southern vault covers the entrance, spanning from the door to the first half of the landing slab, while the higher vault represents the proper soffit of the chamber. Two rectangular cross-vaulted recesses characterize the east and west perimeter walls.
The cross-vault is an architectural solution used by Maya architects to reduce the weight of the structure's roof that spanned the interior doorways of several temples and buildings (Figure 5; Marken 2007: 62; Schele 1986:118).

The chamber's northern wall includes a shallow niche that does not affect the end-vault unit and is interpreted as a sealed door (Loten and Pendergast 1984:25). The niches and the entrance walls are decorated with stucco reliefs of nine figures similar to Temple XX's tomb's painted figures (Greene Robertson 2000). The chamber floor, which lies below the plaza level, has a south-north inclination, and it is composed of big limestone slabs. A "psychoduct," or an open tube-like structure or round cavity that allowed the deceased's soul to travel when called back, connects the chamber with the upper Temple (Schele 1986:123; Stuart and Stuart 2008: 119). Ruz Lhuillier observed that the psychoduct seems to start from below the sarcophagus in a limestone serpent shape. It then ascends through a hollow stone tube carefully constructed on the side of the stairway, reaching the slab on the Temple's floor that gave access to the shaft (Ruz Lhuillier 2013:269; Schele 1986:121).

\section{The Stepped Platform Building Connecting the Temples}

During his first excavation season in 1949, Ruz Lhuillier probed the structure located between the Temple of the Inscriptions and Temple XIII. 


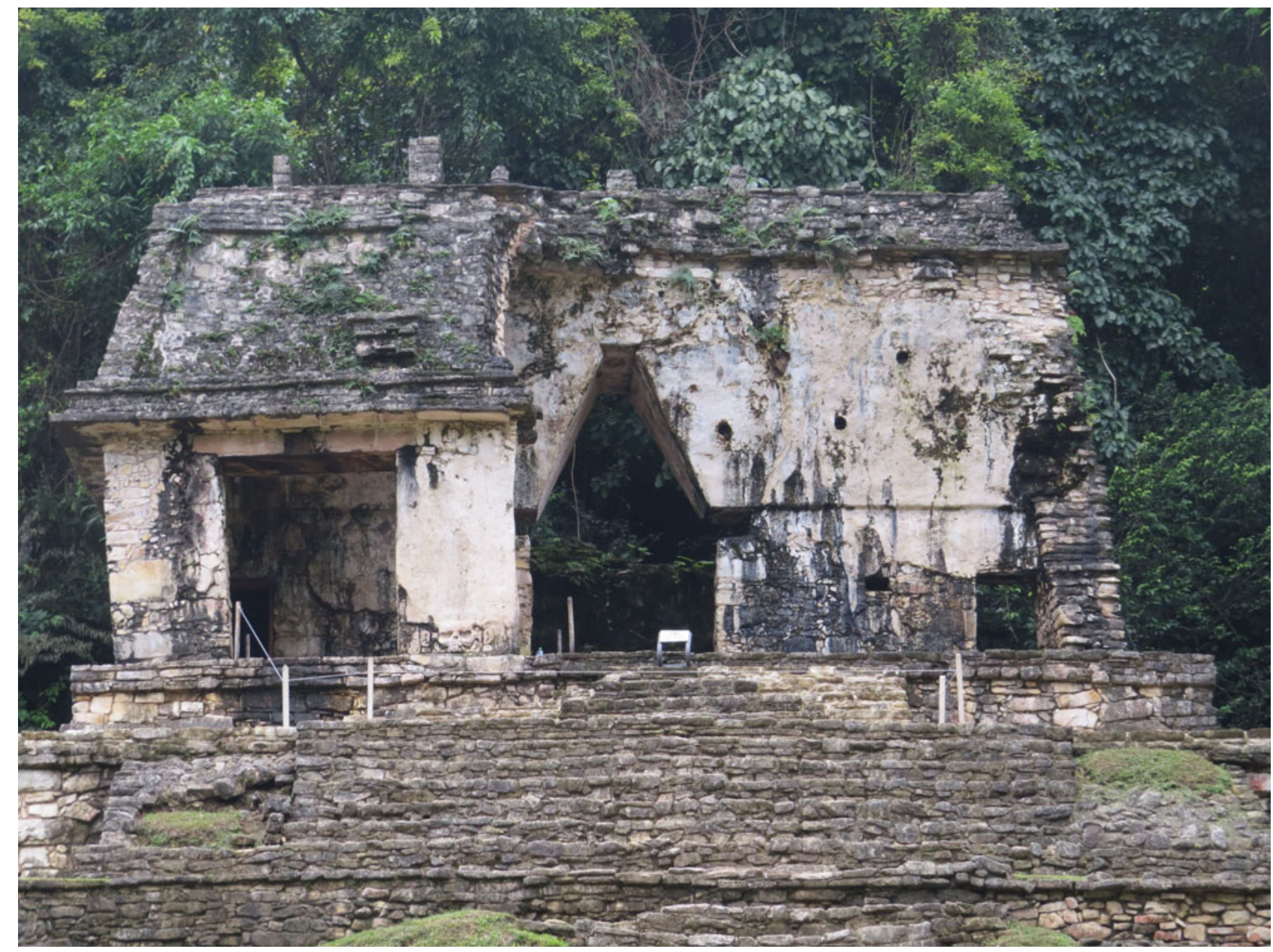

Figure 5. The cross-vault encompasses the central door in Temple XII's central wall. Photograph courtesy of Esteban Mirón Marván.

Trench 6 was meant to define the shape of the basal platform, which Ruz Lhuillier (2013:45, authors' translation) described as "probably attached to the pyramid and that works as the base for a small patio that separates the pyramid from Temple XIII." The platform building connecting the temples is composed of four segments. Ruz Lhuillier described these parts as a vertical upper section and three lower partitions sloping inward, characterized by upper and basal moldings. Along with Trench 6 (Cala 6), Ruz Lhuillier (2013:45) dug Trench 7 (Cala 7) to define the aforementioned dimensions of the small patio and uncover the west façade of the Temple of the Inscriptions.

In 1950, Ruz Lhuillier excavated the interior stairway of the Temple during his second field season. He noted two vaulted openings coming from the landing between the two ramps that seemed to extend outward in the direction of Temple XIII. In 1951, when removing the infill from the stairway, Ruz Lhuillier cleared those openings and described them as two 8-m-long narrow vaulted galleries. He interpreted the openings as ventilation windows, or respiraderos (Ruz Lhuillier 2013:62-63). These two passages open toward an earlier patio level of the stepped platform building separating the Temple of the Inscriptions and Temple XIII, almost three meters below the later patio. According to Ruz Lhuillier (2013:62-63), the respiraderos were sealed with debris when use of the stairway leading to Pakal's tomb terminated (Rands 1954:14).

\section{Temple XIII}

Like its adjacent buildings, Temple XIII abuts against the Sierra de Chiapas. It is composed of a stepped, truncated pyramid made of five segments, on top of which the temple proper stands on a two-stepped rectangular platform with a central stairway flanked by alfardas. The superstructure of the temple had three doors. It was found almost entirely collapsed. It consisted of two, parallel, east-west vaulted galleries, where the rear one was subdivided into three separate rooms. In 1994, while restoring the stairway at the center of the truncated pyramid basal platform, in correspondence with the second segment, González Cruz (2011:102) found a sealed door that provided access to a north-south oriented corridor inside the building. This 6-m long passage leads into another corridor that surrounds a funerary building with three chambers. The substructure stands on a $30 \mathrm{~cm}$ low base platform and resembles a temple building: its exterior exhibits medial molding on three sides. The southern façade has not yet been excavated. This medial molding is part of the vault spring for the corridor's roof. As observed at several other Palenque-style temples, the medial molding corners consist of huge square limestone slabs that support the roof's infill (Andrews 1978:13; González Cruz 2011: 104). While the façade of the funerary building has an east-west orientation, the main axis for the three inner chambers is north-south. The central chamber, which was found sealed, hosts the 
sarcophagus of the Red Queen, a monolithic limestone block painted red on its four sides and closed by a huge limestone slab where the red painting had faded away (González Cruz 2011: $116)$. The presence of a tiny round cavity $(3.5 \mathrm{~cm}$ diameter) that goes through this slab has been interpreted as a psychoduct (González Cruz 2011:117). The chamber's south wall encloses a few steps leading to a central door, sealed from the outside. Even if it is not clear to where this door leads, González Cruz (2011: 113) argued that it was the chamber's main entrance. Four additional sealed doors leading to the outside are also found in the corridor. This passage is characterized by an inverted C-shape layout, surrounding the substructure. Two doors are located at the end of its east-west section, while the other two are at its southern edges. When the first doors were excavated, it was observed that these were passageways ascending with ramps toward the main plaza (González Cruz 2011:117, 125). The other two southern doors also appeared to give access to passageways leading toward the surface. During their excavation, González's team tried to find access to these passageways from the outside. The test pits sounding the seventh segment of the basal platform, however, were too dangerous to excavate. Therefore, the archaeologists could not determine whether the passageways reached the basal platform's seventh segment or to where they led (González Cruz 2011:112).

\section{BACKGROUND ON THE APPLICATION OF 3D DOCUMENTATION METHODS IN THE MAYA AREA}

This section reviews the metric surveying and remote sensing methods employed in this study to provide readers with a background on the prior application of these $3 \mathrm{D}$ technologies in the Maya area.

In the last decade, the increasing availability of airborne LiDAR technology, also known as Aerial Laser Scanning (ALS), has revolutionized the archaeological investigation of Mesoamerica's densely forested regions. ALS enables remote measurements of the underlying elevation of the Earth's surface and human-made structures on the landscape. This capability produces detailed topographic data for mapping and site reconnaissance purposes or investigating land use and landscape modification in antiquity (Canuto et al. 2018; Chase et al. 2011, 2014; Hare et al. 2014; Inomata et al. 2017, 2018, 2020; Opitz 2016; Opitz and Cowley 2012; Reese-Taylor et al. 2016; von Schwerin et al. 2016).

Despite its wide adoption in studying the ancient Maya landscape, ALS is not the most suitable metric survey technique for documenting archaeological excavations and buildings at the intrasite level (Boardman and Bryan 2018; Lercari 2016; Vosselman and Maas 2010). Alternative close-range LiDAR techniques, such as TLS, are much more effective in delivering ultra-precise measurements of the morphology of stratigraphic layers (Doneus and Neubauer 2005b; Galeazzi 2016) and high-fidelity 3D point representations of archaeological surfaces and built structures (Forte et al. 2012; Lercari 2019). Most significantly for Maya archaeology, TLS is capable of recording building substructures uncovered through tunnel excavations and capturing with millimeter-level accuracy archaeological features retrieved in caves, buildings, and plazas (e.g., stucco masks and friezes, hieroglyphic panels, and stelae; Galeazzi 2016; Golden et al. 2020; Merlo et al. 2012, 2017; Tokovinine and Estrada-Belli 2017). Besides allowing building monitoring overtime (Kováč et al. 2015; Vidal Lorenzo et al. 2017), 3D data provide the basis for the virtual reconstruction or reassembling of monuments in GIS and virtual reality (Remondino et al. 2009; Richards-Rissetto et al. 2013).

Since the 2010s, drone-based SfM has proven very effective in documenting entire excavations and enabling low-cost investigation of the archaeological built environment and landscape (FernándezHernandez et al. 2015; Fernández-Lozano and Gutiérrez-Alonso 2016; O'Driscoll 2018; Verhoeven 2011; Waagen 2019; Wernke et al. 2014). In the Maya area, due to the dense forest canopy covering most archaeological sites, the applicability of drone-based documentation techniques is more efficient in deforested zones (Murtha et al. 2019) or where the vegetation has been partially cleared (Lercari et al. 2018).

Most significantly for this study, LiDAR and SfM data can be successfully combined in the same analytical environment to contextualize ancient buildings and relate them to their immediate surroundings (Holata et al. 2018; Lambers et al. 2007; Nex and Rinaudo 2011; Smith et al. 2014). This data fusion technique also enables a new way to investigate ancient structures from different perspectives, generate drawings extrapolated from the 3D models, and spatially relate archaeological findings (Houston et al. 2015; Vidal Lorenzo et al. 2017).

\section{METHODS}

The long history of archaeological research at Palenque has generally focused on the ancient city's central sector. Most of the restored structures visible today are related to civic spaces where many ceremonial activities were performed. The public nature of these spaces suggests that ceremonial activities would have been highly relevant for most people who lived within and beyond the city limits (Liendo Stuardo et al. 2014). To enhance interpretation, we have carefully analyzed Palenque's mortuary practices and the associated elite funerary architecture. We focused on the Temple of the Inscriptions, Temple XII, Temple XIII, Temple XVIII-A, and Temple XX, where archaeologists have recovered remarkable mortuary contexts.

Our methodology combines the analysis of legacy data documenting the structures listed above with TLS and SfM data, collected at Palenque in 2018.

The digital methods presented herein allowed us to enhance our architectural analysis of the case study by adding 3D layers of archaeological and architectural information to the plans, elevations, and cross sections made available by previous excavations. We utilized this wealth of information to visually superimpose and inspect their construction phases and substructures (Figure 6).

\section{Surveying the Temple of the Inscriptions through Terrestrial LiDAR and SfM}

Our architectural analysis of the Temple of the Inscriptions is grounded in new remote sensing data collected by TLS and dronebased SfM (Figure 7).

To produce the hyperprecise $3 \mathrm{D}$ point clouds (sets of measurements defined by $\mathrm{X}, \mathrm{Y}$, and $\mathrm{Z}$ coordinates) of the Temple of the Inscriptions, we needed to compare this building's architectural level and its substructures with those of nearby Temple XIII. We adapted proven TLS surveying and data processing workflows to our case study (Doneus and Neubauer 2005a; Olsen 2015; Olsen et al. 2009). Accordingly, we laser scanned the building on top of the Temple of the Inscription's basal platform recording its external walls with the sculpted figures on the ramps and the stucco reliefs on the external 


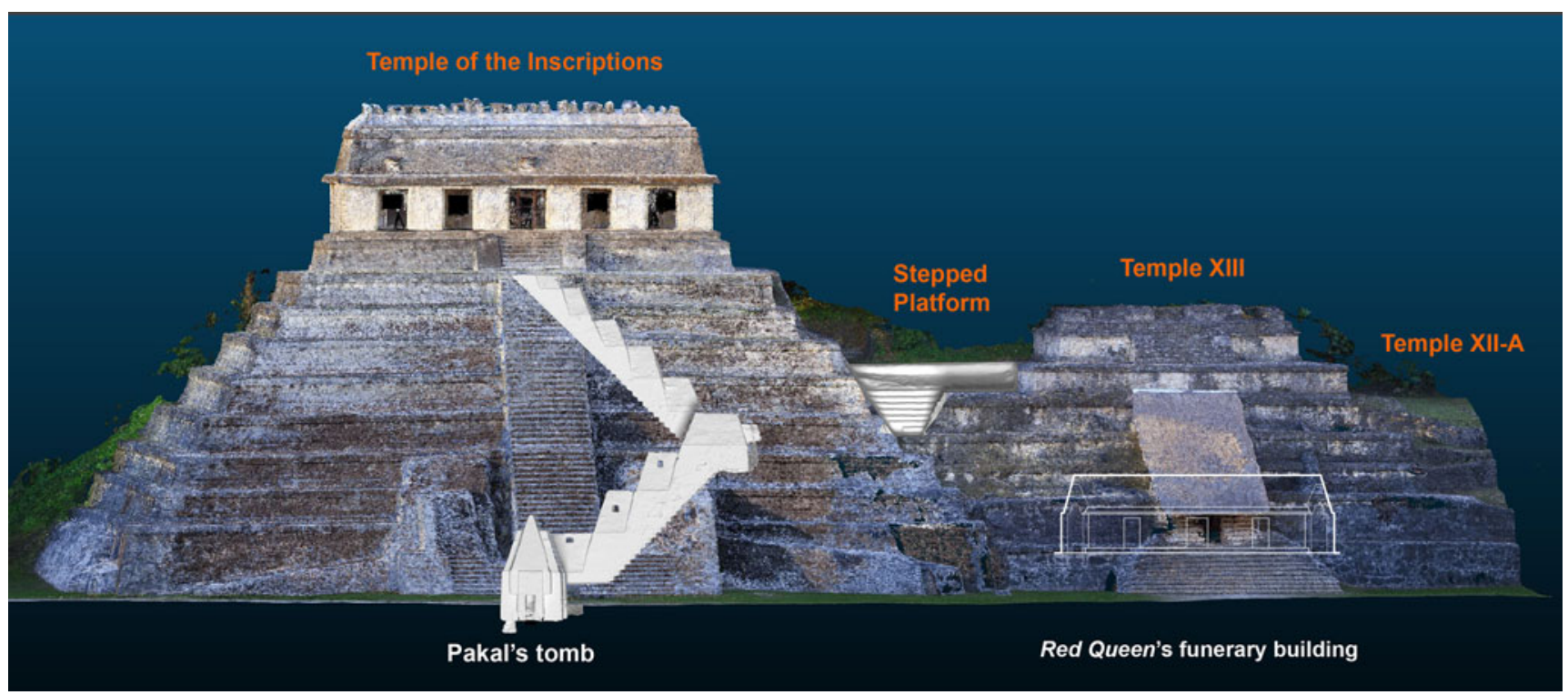

Figure 6. Composite visualization of the northern façades of the Temple of the Inscriptions, Temple XIII, and the stepped platform building and their substructures. Structure from Motion 3D models (color) are seen superimposed with a Terrestrial Laser Scanning 3D model (solid light gray) and architectural drawings (thin white lines). The elevations of Temple XIII's inner chambers were digitized from González Cruz 2011. Image by Campiani and Lercari.

piers. We have also used TLS to document its interior, including the famous limestone tablets (Maudslay 1887; Ruz Lhuillier 2013: 29-41), shafts, and underground spaces (Figures 8 and 9).

To contextualize the Temple of the Inscriptions within the mausoleum architectural project, we conducted a metric survey of the entire site-core. We utilized low-altitude photographs collected through a DJI Inspire 1/RAW drone equipped with a Zenmuse X5 RGB camera and SfM methods. Using these methods, we overcame the challenges of mapping Palenque's city center from the ground where the tropical vegetation and the numerous visitors flocking the site during the time we were in the field would have made this task more time-consuming and less precise.

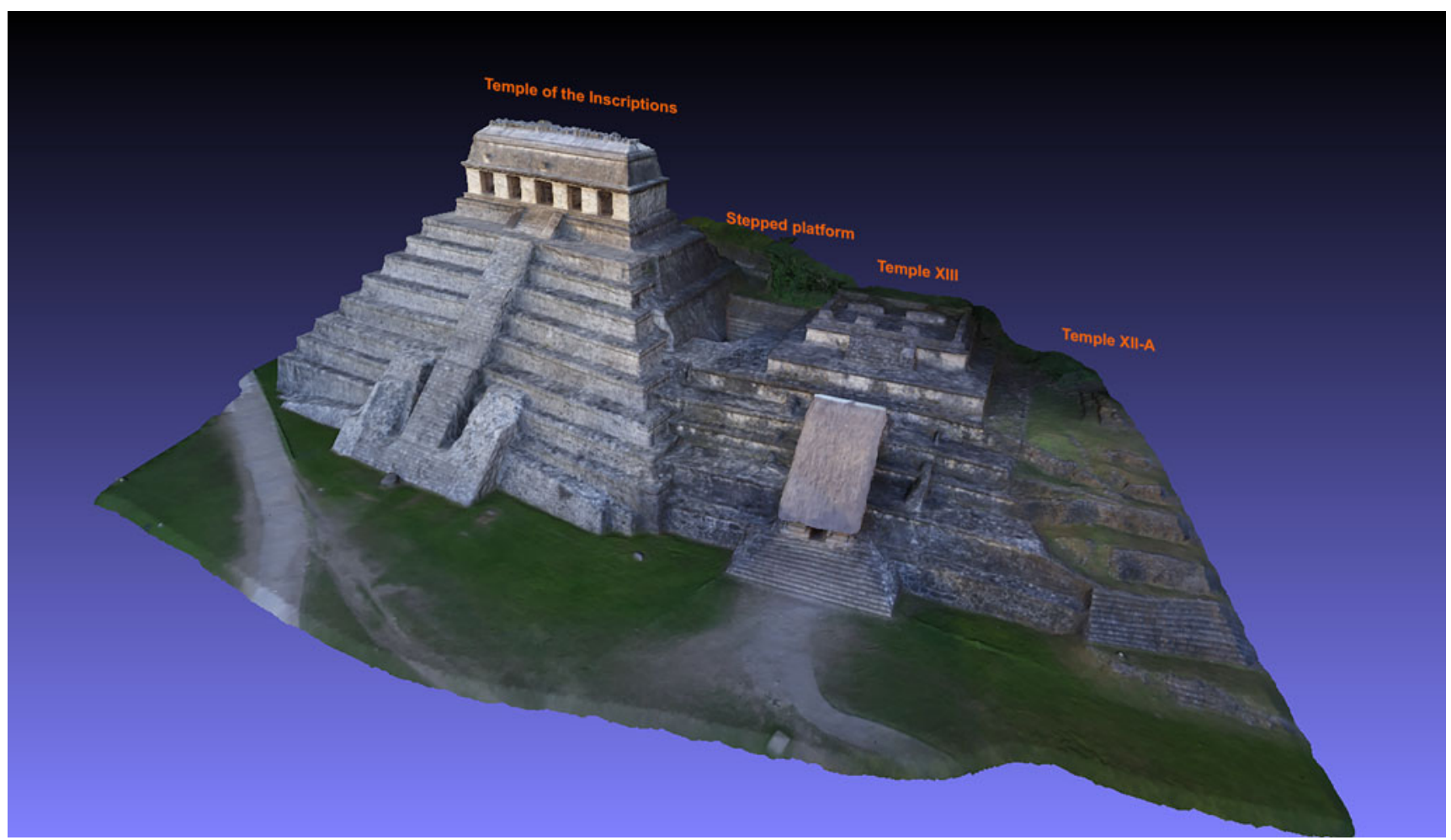

Figure 7. Perspective 3D render displaying Pakal's mausoleum architectural project buildings. Image by Campiani and Lercari. 


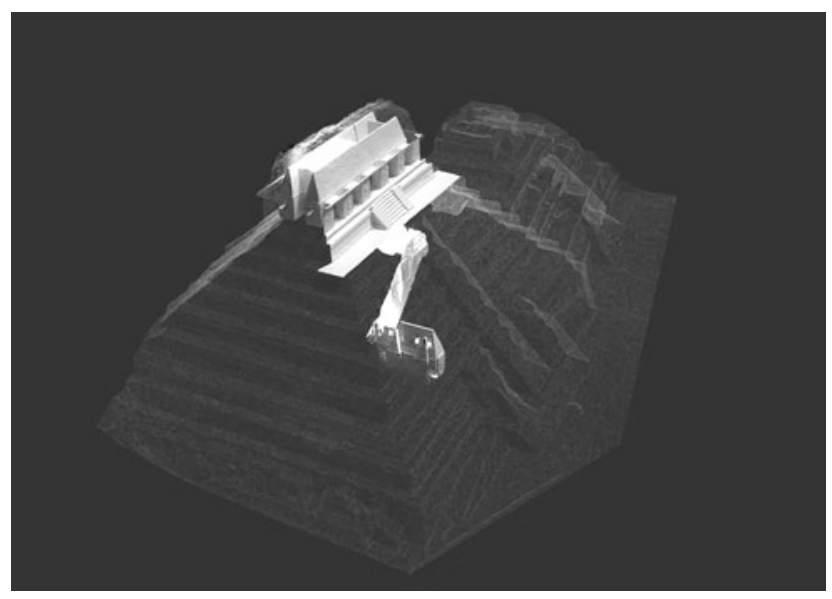

Figure 8. The Temple of the Inscriptions' interior and Pakal's funerary chamber (light gray) and the Temple's exterior and its basal platform (transparent gray) are seen in this perspective 3D render. Image by Lercari and Campiani.
To georeference the individual TLS scans and align the Temple's comprehensive point cloud with the site-core's SfM data, we utilized a standard topographic survey workflow based on triangulation by a total station (DiBiase 1997). Because no permanent control network is available at the site, we followed a conventional method that involves setting the primary project datum point to an arbitrary coordinate (Schneider and Panich 2008). In this way, we recorded our temporary ground control points for both the TLS and SfM surveys.

To align our grid with the site map, we recorded several known architectural elements of buildings throughout the site-core that are recognizable in Barnhart's (2001) plan. Finally, we converted our local coordinates to WGS84 (Figure 10).

\section{Enhancing Architectural Analysis through Datafication}

To complete our architectural analysis of the Temple of the Inscriptions and Temple XIII, we integrated the heterogeneous corpus of accessible data. This collection includes the buildings'

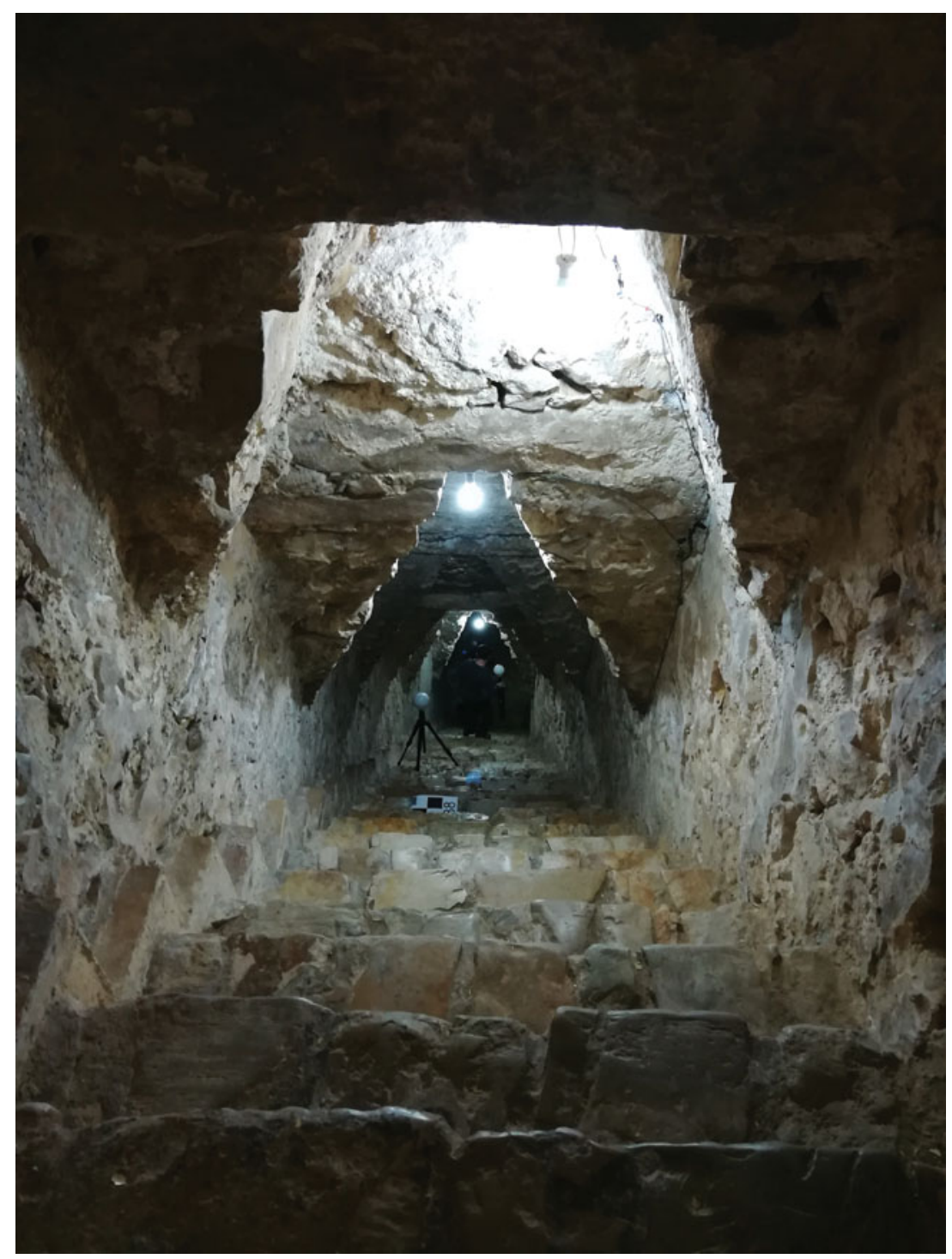

Figure 9. The shaft providing access to Pakal's tomb, the target spheres, and paper targets used as control points in our 3D survey. Photograph by Campiani. 


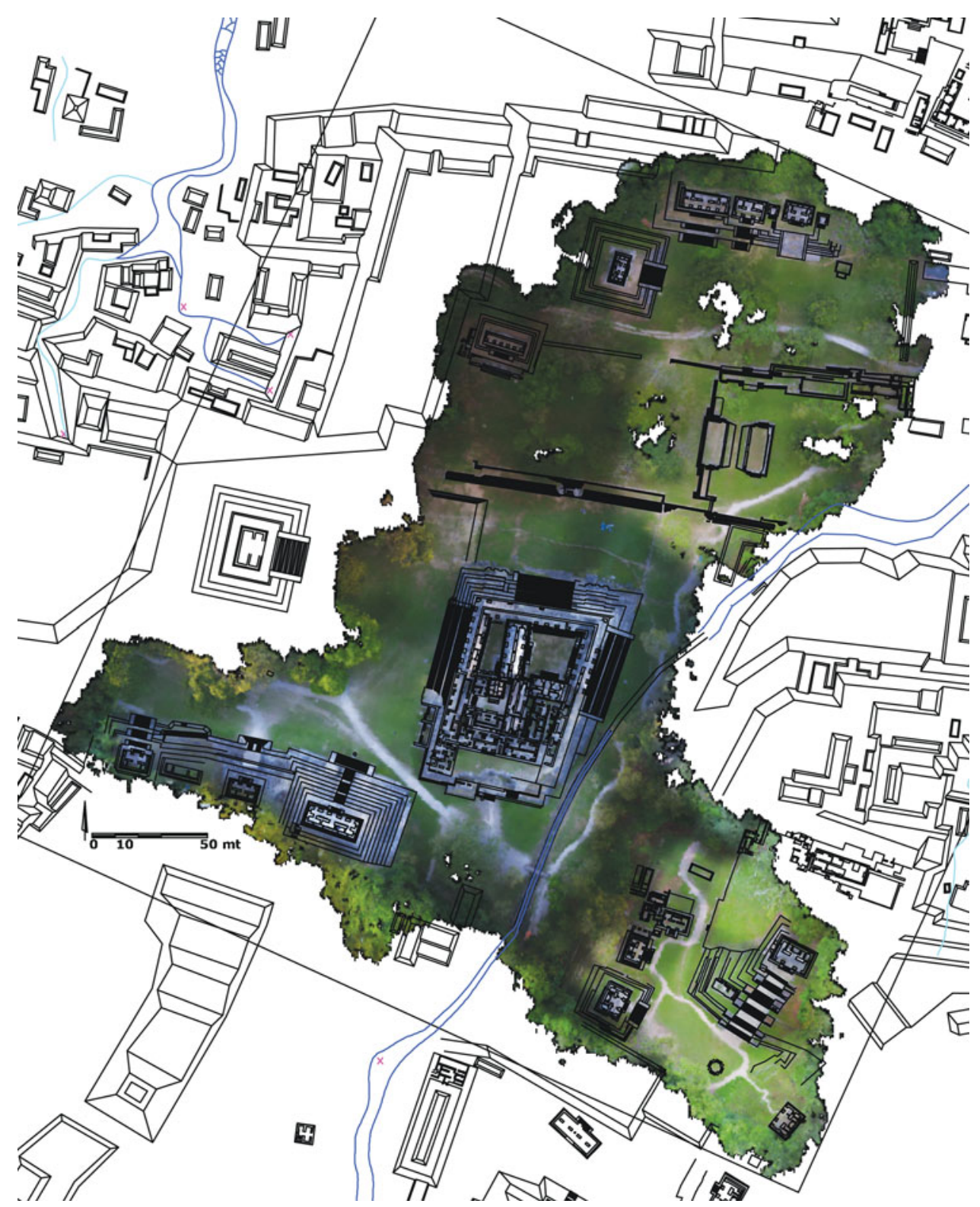

Figure 10. Orthomosaic of Palenque's site-core generated using drone-based Structure from Motion (SfM) overlapped with Palenque's map. Image by Campiani, modified from Barnhart (2001).

published architectural maps and our team's 3D data (Andrews 1978; Barnhart 2001; González Cruz 2011; Ruz Lhuillier 2013).

The data were combined using a computer-aided design (CAD) environment: the ground control points coordinates were precisely plotted on Barnhart's map using the known visible architectural elements and the orthomosaic obtained from digital photogrammetry. Once both the orthomosaic and the chamber's image were situated on Barnhart's map, we digitized the burial chamber's layout and the inner stairs' silhouette showing the respiraderos' location. We then outlined the patio of the stepped building platform lying between the Temple of the Inscriptions and Temple XIII.

To identify the possible correspondence of architectural phases, we needed to consider the buildings in three dimensions and, thus, count on longitudinal and transversal cross sections of the façades of both the Temple of the Inscriptions and Temple XIII. We generated this architectural analysis material directly from the 3D models: the point clouds of the Temple of the Inscription were triangulated in MeshLab (Cignoni et al. 2008) then exported as a triangular mesh 3D model. We then imported this 3D dataset and the mesh generated via the SfM into the 3D modeling software Blender. Using this application, we confirmed that the 3D models overlapped completely. By applying transparency effects and Boolean operations in Blender, we sliced the two models, observed the relations between the buildings and their construction levels, and finally imported orthogonal drawings and cross sections into the $\mathrm{CAD}$ environment.

To complete the architectural analysis of Temple XIII, we relied on the elevation, plan, and cross section drawings published by González Cruz (2011). We also utilized the 3D data of Temple XIII generated through SfM to locate substructures where the Red Queen was buried. Specifically, we overlapped González's elevation drawing with the photogrammetric orthogonal front image of Temple XIII. Then we used the access door as a guide to locate 


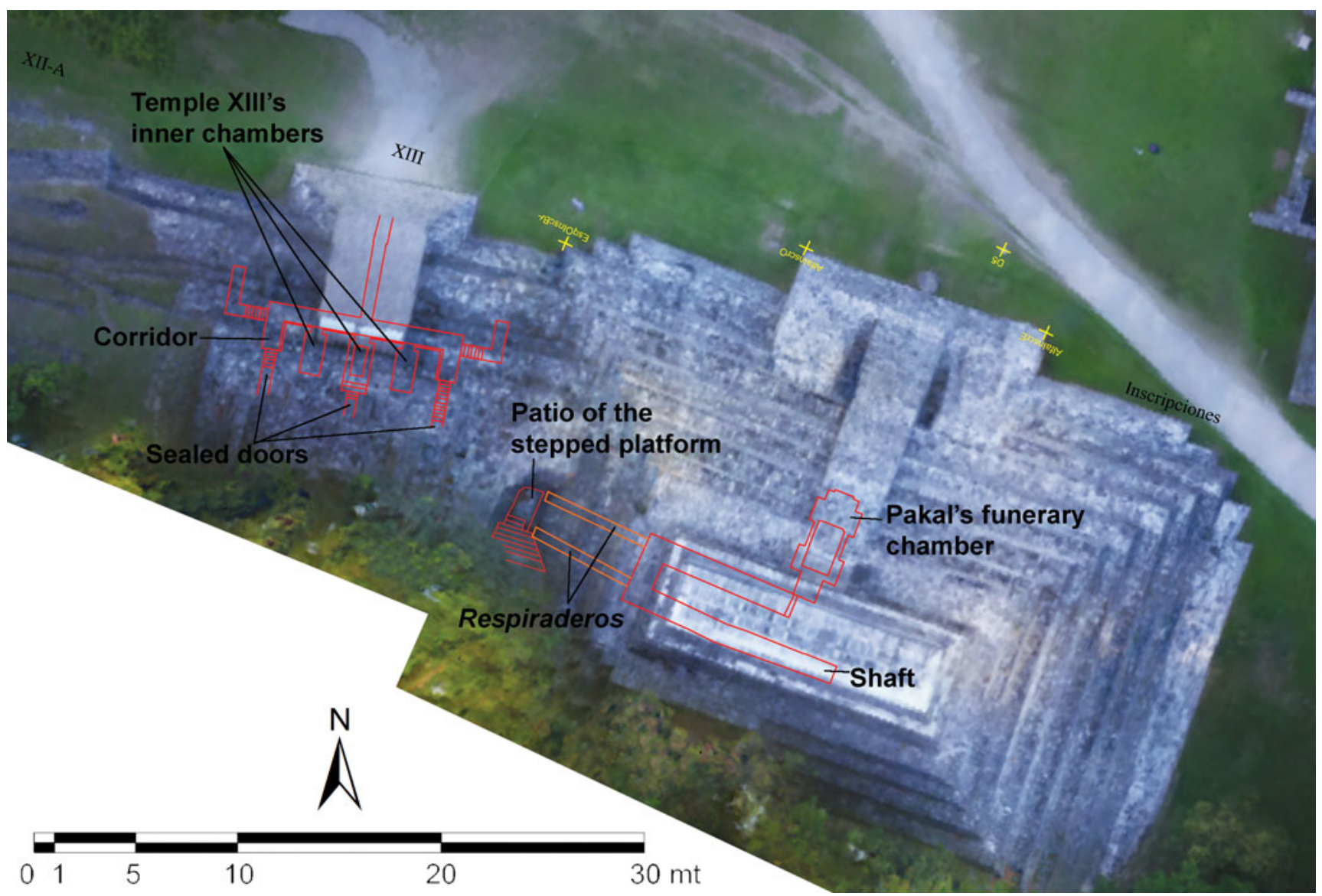

Figure 11. Digitized architectural drawings (red lines) of the Temple of the Inscriptions' and Temple XIII's tombs. The drawings are seen in CAD overlapped with a section of the orthophoto of Palenque's site-core. Temple XIII's inner chambers' plans digitized from González Cruz 2011. 3D models and drawings by the Campiani and Lercari.

the funerary chamber, both in plan and elevation. We finally digitized architectural drawings from both temples and overlapped them in CAD with an orthomosaic of the south-west end of the sitecore generated via SfM (Figure 11).

\section{RESULTS}

Following Richards-Rissetto and Landau (2019:122), we performed datafication through the following steps: (1) reanalysis of Palenque's archaeological record; (2) digitization of the original drawings of Pakal's mausoleum buildings; (3) integration of these legacy data with the 3D data we collected in 2018; and (4) enhanced architectural analysis.

Specifically, we identified three possible scenarios related to the construction of the Temple of the Inscriptions. Two of the hypotheses presented in the following pages were proposed earlier by other researchers investigating Palenque. In contrast, the third hypothesis originates from the architectural analysis informed by our geospatial and $3 \mathrm{D}$ data.

Previous Hypotheses on the Construction of the Temple of the Inscriptions

Ruz Lhuillier (2013) and Schele (1986) proposed the first hypothesis regarding the Temple of the Inscriptions' construction. According to their interpretation, the Temple and Pakal's tomb were part of the same architectural program. Because of the size and mass of the Temple's basal platform, this hypothesis suggests that the sarcophagus inside the chamber was positioned and sculpted in situ and protected by walls and sand during the construction of the surrounding room and its corbelled vault.

Schele (1986:120) went even further and suggested that Pakal would have supervised his tomb's construction and decoration firsthand. She also stated that the tomb's layout would have emulated the Early Classic tomb of Temple XVIII-A. According to the vessels deposited in the cist, Rands situated the burial exposed in Temple XVIII-A in the Early Classic period (A.D. 400-600; Schele 1986:115). She suggested that the male individual buried in this tomb could have been Ahkal Mo' Nahb' I (called in the article Chaacal I), one of Palenque's ruling dynasty's founders (Schele 1986:116). This individual is mentioned in the Temple of the Inscriptions' epigraphic record and represented on the lid of Pakal's sarcophagus.

Nonetheless, recent radiocarbon dating performed by Couoh Hernández and Cuevas García (2015) readjusted the dating for this individual to A.D. 250-420. This new evidence dates the burial to a period predating the foundation of Palenque's dynasty, therefore confuting Rand's initial interpretation. Whoever was buried in Temple XVIII-A, his tomb's layout is evocative of the later funerary chambers unearthed on-site. 


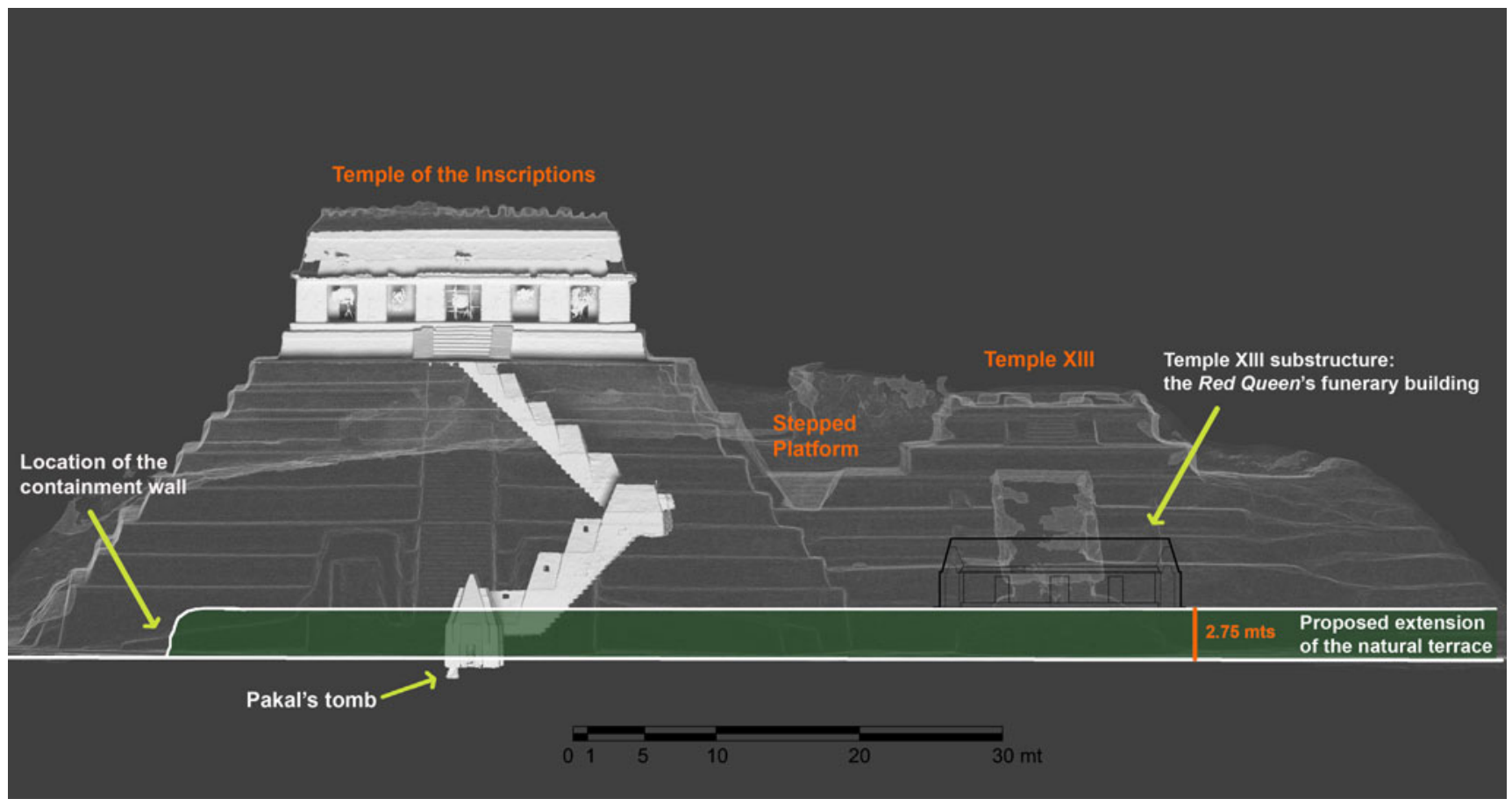

Figure 12. Composite visualization of the northern façades of the Temple of the Inscriptions and surrounding buildings. The integration of 3D renders and digitized drawings highlights the natural terrace (green area) beneath the buildings. Temple XIII's inner chambers' elevation digitized from González Cruz 2011. 3D models and drawings by Campiani and Lercari.

Of note for our architectural analysis, the tomb's major axis is north-south, with the burial's head oriented to the north. The vaulted-roof chamber was accessible through a stair from an outside platform, and large, single slabs sealed the door. Previous excavations documented a vertical stone tube emerging from Temple XVIII-A and reaching the tomb's upper sanctuary floor. This tube is undoubtedly an early example of a psychoduct that ancient Maya architects decided to preserve when they erected the Late Classic Temple XVIII-A on top of the earlier structure hosting the tomb, even if the stone tube remains $50 \mathrm{~cm}$ below the new floor.

Recent investigations of the Early Classic tomb in Temple XX unveiled another example of funerary architecture denoting a tripartite layout (González Cruz and Balcells González 2015). The corbelled main chamber also follows a north-south orientation. The doors of the two lateral chambers were sealed with large stone slabs. We believe that the similar layout of each tomb supports our claim regarding a preferred tripartite scheme used in elite burials at Palenque during the Classic period.

Cedillo Álvarez and Villalobos Pérez (2004) formulated the second hypothesis on the construction of the Temple of the Inscriptions. They suggested that the mausoleum was built on top of an earlier temple lying on a low platform. After analyzing the architecture of early temples at Palenque, they suggest that this earlier temple building resembles the Temple of the Count and would have been composed of two parallel, gallery-type rooms oriented east-west. The corridor to the rear, located underneath the central cross-vault, would have been selected to place Pakal's funerary chamber (Cedillo Álvarez and Villalobos Pérez 2004:105, 120, Figure 14). According to Cedillo's and Villalobos' hypothesis, there should be a hidden room on each side of Pakal's funerary chamber. These lateral rooms should correspond to the proper east-west gallery-type rooms of the earlier temple.
New Findings and Interpretations Informed by 3D Data and Architectural Analysis

As mentioned previously, we utilized architectural analysis informed by new geospatial and 3D data to go beyond the two scenarios discussed above and support our argument regarding the Temple of the Inscriptions being part of Pakal's mausoleum architectural project. Specifically, we used new 3D data describing the Temple of the Inscriptions, Temple XIII, and their substructures, along with the stepped platform building connecting them, to compare their architectural levels.

Our findings emphasize striking spatial correspondences that have not been observed before. For instance, we have detected that the level of the tomb of the Red Queen is the same as the earlier level of the central stairway of the Temple of the Inscriptions, lying $2.75 \mathrm{~m}$ above the plaza (Andrews 1978:99; Ruz Lhuillier 2013:99).

Using Ruz Lhuillier's (2013:102) excavation data locating a containment wall to the east of the Temple's basal platform and Rands' (1954) ceramic analysis that attributes this wall to an earlier construction phase, we inferred that this level corresponds to a natural terrace that extended continuously from the center of the eastern part of Temple of the Inscriptions' façade through at least the Red Queen's funerary chamber (Figure 12).

Following Ruz Lhuillier (2013) and Schele (1986), we believe that the Temple of the Inscriptions' builders would have excavated the terrace and extracted construction material for Pakal's tomb. We attribute the level difference between Pakal's tomb - under the plaza level—and the Red Queen's tomb—on the natural terrace- to the presence of spring water underneath the Temple of the Inscriptions as confirmed by recent investigations (Dirección de Medios de Comunicación, INAH 2016). According to González 


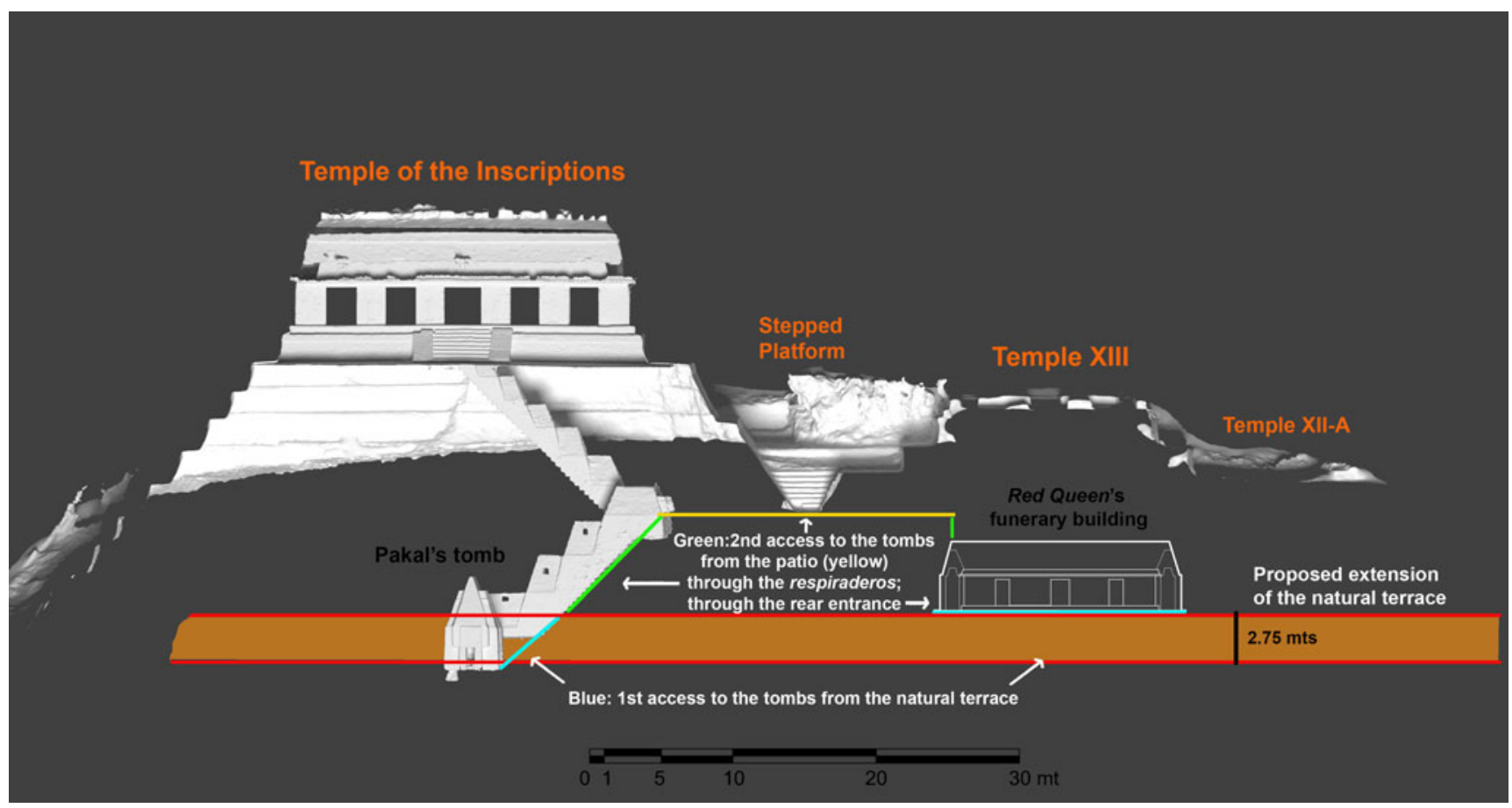

Figure 13. Composite visualization of the northern façades of the Temple of the Inscriptions and Temple XIII, including their substructures. The colored lines indicate the architectural levels of each construction phase. Temple XIII substructure' elevation digitized from González Cruz 2011. 3D models and drawings by Campiani and Lercari.

Cruz, the aqueduct system discovered under the plaza level in front of the Temple of the Inscriptions also runs beneath Pakal's funerary chamber. González Cruz believes that this water infrastructure was built at the beginning of the seventh century before the funerary chamber's construction (Dirección de Medios de Comunicación, INAH 2016). Springwater was an important symbolic element for the ancient Maya that may have motivated Pakal to choose a location above this water source for his tomb.

We further hypothesize that the stairway's first ramp could have been used to access Pakal's funerary chamber from the terrace to perform funerary rituals when the basal platform was being built. As the construction progressed for both the Temple of the Inscriptions and Temple XIII, the lower level of the stepped platform building connecting them would have allowed access to Pakal's chamber through the respiraderos. Similarly, one of the sealed entrances at the rear of Temple XIII's substructure would have provided access to its funerary chambers (Figure 13). Similarly, Temple XII-A could have been a service access point into Temple XIII and Temple XII, confirming our hypothesis that service construction buildings were used to easily allow people to reenter the tombs to perform post mortem rituals. This additional consideration, along with our interpretation of the temples' construction sequence, confirms that the Temple of the Inscriptions and Temple XIII were part of the same mausoleum architectural project.

\section{DISCUSSION}

Our proposal on the existence of a mausoleum architectural project and its analysis were formulated through the new data and interpretations generated through the datafication process discussed above. Without the need for additional excavations, this approach provided new insights on the Temple of the Inscription's construction by considering the characteristics of elite funerary architecture and practices recognized at Palenque.

\section{Palenque's Elite Funerary Architecture and Mortuary Practices}

Decades of systematic archaeological excavations at Palenque have revealed that the city's inhabitants shared beliefs regulating important aspects of daily life, including mortuary practices. These funerary traditions and their associated materiality were strongly structured and formalized and permeated different sectors of Palenque's society, particularly its elite classes. For instance, burials recovered from funerary buildings associated with public worship were likely sponsored by Palenque's elites. These funerary contexts display a sophisticated system of beliefs represented in the city's art and iconography. Accordingly, after death, a person undergoes a journey to the underworld, including overcoming numerous dangers and challenges. At the end of the journey, the deceased is reborn through a process that resembles the sprouting of a maize plant or the Sun rising, a symbol connected to Maya rulers (Baudez 1996). Finally, the reborn reaches the sky's higher levels, becoming a communal ancestral deity (Coe 1999; Schele and Miller 1992).

The funerary practices shared among the Classic Maya include the systematic removal of bones from the graves, the pervasive reentering of burials, and recurring funerary architectural elements. These funerary practices could be interpreted as an elite discursive strategy geared toward creating a shared notion of history and place among the ruling family and the local population (Marken et al. 2017:193).

Our analysis of Palenque's archaeological record shows that the repetition of architectural features and elite funerary practices can be 
grouped in one of the following mutually exclusive categories: (1) East-facing shrines hosting simple crypts characterized by a central elongated space where distinguished individuals' remains were deposited and two lateral niches with votive offerings (i.e., the J7 early burial in Group IV); (2) A tripartite layout comprised of funerary substructures made of three adjacent rooms (i.e., Temple XIII and Temple XX) or slab-crypts (i.e., Temple XV and Templo Olvidado).

A common element between these two categories is that the body and its container were laid out using a preferred north-south orientation, with the head facing north (i.e., Pakal's and the Red Queen's burials, or the subfloor burials in the Cross Group). Mausoleum reentry and removal of portions of the skeleton were also widely shared funerary practices. Examples of category 1 funerary practices are the simple crypts with niches on the elongated container's sidewalls, which are associated with the oldest and most recurrent funerary architectural layout at Palenque (Johnson 2018; Scherer 2018; Welsh 1988). According to Ruz's Lhuillier (1961) description, one of the oldest elite burials at Palenque under Temple XVIII-A follows a similar layout. Two elite individuals were buried in this cruciform vaulted tomb. Because of their burial location in the South Acropolis, a restricted area of the site, Ruz Lhuillier (1961) suggested these individuals were members of the city's ruling dynasty.

In category 2, the tomb excavated under Temple XX shows a similar tripartite architectural scheme. Two exterior rooms flank the main chamber, one on each side of the central door (González Cruz and Balcells González 2015; Greene Robertson 2000, 2001). Inside the main room that was adorned with early mural paintings, archaeologists uncovered the remains of what might have been a rich offering. The body lying in this space was probably removed in pre-Hispanic times; however, limited contextual information was reported during excavations (González Cruz and Balcells González 2015:96).

Elaborating on the evidence presented above, we identified an evolution in the containers' layout that housed the mortuary remains of selected individuals at Palenque through time. In royal contexts, this design evolved from a north-south oriented tomb with niches on the sides and a vaulted roof (i.e., the tomb of Temple XVIII-A) to a more elaborated tripartite scheme where the tomb with three vaulted rooms often resembles a building (i.e., Temple XX and Temple XIII). Such a design involved the construction of three north-south burial chambers to house the body of prominent individuals.

\section{Pakal's Tomb Tripartite Layout}

Our analysis of Palenque's elite funerary practices and architecture indicates that the Temple of the Inscriptions' substructure may follow the tripartite layout we observed in Temple XVIII-A, Temple XX, and Temple XIII. Accordingly, we concur that Pakal's tomb is located in the central chamber of a funerary building composed of three north-south oriented rooms.

To reassess Cedillo's and Villalobos' interpretation of Pakal's tomb, we followed Marken's (2007) description of Palenque's temples with cross-vaults. We verified that there are no examples where the cross-vault is higher than the longitudinal rooms it connects (Marken 2007:62-64).

Our TLS data of the Temple of the Inscriptions confirm that this structure is the building with the highest cross-vaults whose upper parts reach the main galleries' capstone. Besides this structural observation, an additional element that disproves previous hypotheses claiming that the royal tombs within Pakal's mausoleum project were located within earlier temples comes from the observation of Temple XIII's substructure. Even though the façade of this funerary building resembles a temple, there is no evidence of temple buildings where the façade is perpendicular to the inner rooms, as occurs in Temple XIII. It is important, however, to underline that Scherer (2012:253) suggested that Pakal started a mortuary practice tradition at Palenque that involved three north-south oriented slab-crypts associated with sarcophagi, where the earlier example was the grave of his parents in Templo Olvidado. Although the latter observation highlights similarities between the Templo Olvidado, Temple XV, and the Red Queen's tomb, our interpretation differs from Scherer's, as we stress the resemblance between the tripartite layout tombs uncovered in Pakal's mausoleum and an actual building.

\section{CONCLUSIONS}

In the Maya area, TLS and SfM have been mainly used for documenting and conserving highly endangered, buried, and valuable buildings and their artistic features. Several scholars, however, have recently encouraged us to go beyond digital data acquisition by taking advantage of 3D data's potential to answer archaeological questions (Richards-Rissetto and Landau 2019; Roosevelt et al. 2015). Following this recommendation and building on our expertise on drone-based SfM and TLS survey techniques, this article proposed a new interpretation of a group of paramount funerary buildings at Palenque.

We believe our results demonstrate that Pakal sponsored the construction of the Temple of the Inscriptions, Temple XIII, and the stepped platform building connecting them as part of a single monumental architectural project. Following Fitzsimmons's (2009: 180-181) theory on the symbolic choice of a king's burial place, we conclude that Pakal promoted the construction of this project in the southwest part of Palenque's site-core to enshrine in perpetuity the social and political prestige and power of his ruling dynasty and ancestors.

Building on our 3D data and architectural analyses, we also verified that, during the construction of Pakal's mausoleums, the ritual specialists and ruling class used adjacent service buildings to access the mortuary chambers to perform post mortem rituals. Specifically, they used the stepped platform buildings between the Temple of the Inscriptions and Temple XIII and Temple XII for this purpose.

We complemented this study by carefully analyzing elite funerary practices and architecture at Palenque. We observed that the funerary substructures of several temples were built following a tripartite layout consisting of three parallel chambers oriented northsouth featuring corbelled roofs. By deduction, these similarities led us to infer that the Temple of the Inscription's substructure follows the same tripartite layout, therefore overcoming the limited availability of excavation data currently restricted to Pakal's funerary chamber.

To conclude, this article provided a clear example of successfully combining 3D data with legacy archaeological information and anthropological knowledge to tackle unanswered archaeological dilemmas. Future work at Palenque may use the proposed methods to uncover new evidence on previously excavated buildings or facilitate interpretation of newly excavated elite mortuary contexts. Our approach's applicability goes beyond our area of study and can be used at other archaeological sites presenting similar characteristics. 


\section{RESUMEN}

El Templo de las Inscripciones es probablemente el ejemplo más conocido de un edificio funerario construido para conmemorar a un gobernante maya. Es un excelente muestra de conocimiento arquitectónico, combinado con abundantes y extensos textos jeroglíficos relacionados con aspectos complejos de la religión y la historia. Construido en el siglo siete d.C., guarda en su interior, una magnífica cámara abovedada en donde se encuentra un masivo sarcófago labrado que resguarda los restos de K'inich Janab Pakal.

Tanto su secuencia constructiva, como la probable existencia de habitaciones ocultas en los lados de la cámara han sido objeto de discusión entre los arqueólogos a lo largo de los años. En este artículo queremos contestar a esta interrogante y entender el edificio en su contexto arquitectónico a partir de nuevos datos digitales obtenidos con fotogrametría con drones y LiDAR terrestre. Después de analizar cómo estas técnicas se han utilizado en el área maya, demostramos cómo los datos 3D generados pueden servir junto con datos procedentes de publicaciones y reportes para contestar preguntas arqueológicas. Gracias al análisis arquitectónico que incorpora todos estos tipos de datos hemos observado nuevas correspondencias que nos llevan a proponer que el Templo de las Inscripciones formó parte de un proyecto arquitectónico mayor impulsado por Pakal que involucró también la construcción del Templo XIII, donde yacen los restos de la "Reina Roja," probablemente su consorte, la señora Tz'akbu Ahau. El basamento escalonado entre el Templo de las Inscripciones y el Templo XIII también formaría parte de este proyecto arquitectónico y se hubiera construido para consentir el acceso a las cámaras mortuorias de Pakal y de la "Reina Roja" mientras los basamentos de los dos edificios se encontraban en construcción. Para encontrar una explicación a las correspondencias observadas entre los mausoleos tuvimos que revisar las prácticas funerarias adoptadas en Palenque. Gracias a la observación de las características arquitectónicas de las tumbas de élite, proponemos la predilección de un esquema tripartido en su diseño, en donde las subestructuras funerarias se organizarían en tres cuartos orientados norte-sur. Siguiendo esta lógica, pensamos que también a los lados de la cámara funeraria de K'inich Janab Pakal habría otros dos cuartos.

\section{ACKNOWLEDGMENTS}

We thank Atasta Flores Esquivel for leading our topographic surveying at Palenque, and Manuel Dueñas García for standardizing our data and creating $3 \mathrm{D}$ renders in Blender. We are grateful to Rosemary Joyce, Davide Domenici, and Luis Núñez Enríquez for providing invaluable suggestions on this research, and to Gina Palefsky for proof-reading our text. Finally, we would also like to acknowledge Arnoldo González Cruz (Centro INAH-Chiapas), Miguel Angel Vázquez del Mercado (Director del Museo de Sitio, Palenque), and Haydeé Orea Magaña (Centro INAH-Chiapas) for contributing to this work with priceless information. This research is part of a project that has received funding from the European Union's Horizon 2020 research and innovation program under the Marie Skłodowska-Curie grant agreement No. 839602, the National Autonomous University of Mexico (UNAM) Humanities Postdoctoral Fellowship Program 2018-II, and the Hellman Family Fellows Award. Funding sources were not involved in the study design, data collection, analysis, interpretation, or decision to submit the article for publication. The permit for our field investigation at Palenque was granted by the Instituto Nacional de Antropología e Historia to Rodrigo Liendo Stuardo, as the

\section{REFERENCES}

Andrews, George F.

1978 Architectural Survey Palenque, Chiapas, Mexico: The Temples. University of Texas Libraries, Alexander Architectural Archive. University of Texas at Austin, Austin. Electronic document, https:// repositories.lib.utexas.edu/handle/2152/14053.

Barnhart, Edwin L.

2001 The Palenque Mapping Project: Settlement and Urbanism at an Ancient Maya City. Unpublished Ph.D. dissertation, Department of Anthropology, University of Texas, Austin.

Baudez, Claude-François

1996 Arquitectura y escenografía en Palenque: Un ritual de entronización. RES: Anthropology and Aesthetics 29-30:172-179.

Boardman, Clide, and Paul Bryan

20183 D Laser Scanning for Heritage. 3rd ed. Historic England, Swindon. Canuto, Marcello A., Francisco Estrada-Belli, Thomas G. Garrison, Stephen D. Houston, Mary Jane Acuña, Milan Kováč, Damien Marken, Philippe Nondédéo, Luke Auld-Thomas, Cyril Castanet, David Chatelain, Carlos R. Chiriboga, Tomáš Drápela, Tibor Lieskovsky, Alexandre Tokovinine, Antolin Velasquez, Juan C. Fernández-Diaz, and Ramesh Shrestha

2018 Ancient Lowland Maya Complexity as Revealed by Airborne Laser Scanning of Northern Guatemala. Science 361:eaau0137. Cedillo Álvarez, Luciano, and Alejandro Villalobos Pérez

2004 Nueva hipótesis sobre la construcción de la Tumba del Templo de
Director of the Project "El Grupo IV de Palenque: Un espacio residencial de élite en la antigua ciudad de Lakamha." All three co-authors conducted fieldwork at Palenque in 2018. Campiani was responsible for formulating the main hypothesis discussed in this article. Additionally, she contributed to collecting the archaeological data, processed the digital data, and created the architectural drawings and figures. As the first author, Campiani was responsible for co-writing the introduction and conclusions, writing the literature background, methods, and results sections, and completing the revise andresubmit. Liendo Stuardo contributed to formulating the main hypothesis and co-writing the introduction and conclusions. He was responsible for contextualizing the funerary architecture practices at Palenque and wrote the related section. Lercari was responsible for co-developing the data capture and processing methods used in this study and collecting the data on-site. He was also responsible for co-writing the introduction and conclusions and writing the literature background, methods, and results sections. Lercari made major edits to all sections and contributed to the revise and resubmit and figure design.

las Inscripciones de Palenque. In El culto funerario en la sociedad maya. Memorias de la Cuarta Mesa Redonda de Palenque, edited by Rafael Cobos, pp. 99-127. Instituto Nacional de Antropología e Historia, Mexico City.

Chase, Arlen F., Diane Z. Chase, Jaime J. Awe, John F. Weishampel, Gyles Iannone, Holley Moyes, Jason Yaeger, and M. Kathryn Brown

2014 The Use of LiDAR in Understanding the Ancient Maya Landscape: Caracol and Western Belize. Advances in Archaeological Practice 2:208-221.

Chase, Arlen F., Diane Z. Chase, John F. Weishampel, Jason B. Drake,

Ramesh L. Shrestha, K. Clint Slatton, Jaime J. Awe, and William E. Carter 2011 Airborne LiDAR, Archaeology, and the Ancient Maya Landscape at Caracol, Belize. Journal of Archaeological Science 38:387-398.

Cignoni, Paolo, Marco Callieri, Massimiliano Corsini, Matteo Dellepiane, Fabio Ganovelli, and Guido Ranzuglia

2008 MeshLab: An Open-Source Mesh Processing Tool. In Sixth Eurographics Italian Chapter Conference, edited by Vittorio Scarano, Rosario De Chiara, and Ugo Erra, pp. 129-136. Eurographics Association, Geneve.

Coe, Michael

1999 The Maya. Thames and Hudson, London.

Couoh Hernández, Lourdes, and Martha Cuevas García

2015 La tumba real del Templo XVIII-A de Palenque, Chiapas. Arqueología Mexicana 23:80-85. 
DiBiase, David

1997 Nature of Geographic Information: An Open Geospatial Textbook. The Pennsylvania State University, State College.

Dirección de Medios de Comunicación, Instituto Nacional de Antropología e Historia

2016 Descubren sistema de canales bajo el Templo de las Inscripciones de Palenque. Arqueología Mexicana, July 26. Electronic document, https://arqueologiamexicana.mx/mexico-antiguo/descubren-sistemade-canales-bajo-el-templo-de-las-inscripciones-de-palenque.

Doneus, Michael, and Wolfgang Neubauer

2005a 3D Laser Scanners on Archaeological Excavations. In Proceedings of the XXth International Symposium CIPA, pp. 226-231. Electronic document, CIPA Heritage Documentation, https:// www.cipaheritagedocumentation.org/wp-content/uploads/2018/12/DoneusNeubauer-3D-laser-scanners-on-archaeological-excavations.pdf.

2005b Laser Scanners for 3D Documentation of Stratigraphic Excavations. In Recording, Modeling and Visualization of Cultural Heritage, edited by Emmanuel Baltsavias, Armin Gruen, Luc Van Gool, and Maria Pateraki, pp. 193-203. Taylor and Francis/Balkema, Leiden.

Fernández-Hernandez, Jesús, Diego González-Aguilera, Pablo

Rodríguez-Gonzálvez, and Juan Mancera-Taboada

2015 Image-Based Modelling from Unmanned Aerial Vehicle (UAV) Photogrammetry: An Effective, Low-Cost Tool for Archaeological Applications. Archaeometry 57:128-145.

Fernández-Lozano, Javier, and Gabriel Gutiérrez-Alonso

2016 Improving Archaeological Prospection Using Localized UAVs Assisted Photogrammetry: An Example from the Roman Gold District of the Eria River Valley (NW Spain). Journal of Archaeological Science: Reports 5:509-520.

Fitzsimmons, James L.

2009 Death and the Classic Maya Kings. University of Texas Press, Austin.

Forte, Maurizio, Nicolo Dell'Unto, Justine Issavi, Lionel Onsurez, and

Nicola Lercari

2012 3D Archaeology at Çatalhöyük. International Journal of Heritage in the Digital Era 1:351-378.

Galeazzi, Fabrizio

2016 Towards the Definition of Best 3D Practices in Archaeology: Assessing 3D Documentation Techniques for Intra-Site Data Recording. Journal of Cultural Heritage 17:159-169.

Garrison, Thomas G., Dustin Richmond, Perry Naughton, Eric Lo, Sabrina

Trinh, Zachary Barnes, Albert Lin, Curt Schurgers, Ryan Kastner, and Sarah E. Newman

2016 Tunnel Vision: Documenting Excavations in Three Dimensions with Lidar Technology. Advances in Archaeological Practice 4: 192-204.

Golden, Charles, Andrew K. Scherer, Stephen Houston, Whittaker Schroder, Shanti Morell-Hart, Socorro del Pilar Jiménez Álvarez, George Van Kollias, Moises Yerath Ramiro Talavera, Mallory Matsumoto, Jeffrey Dobereiner, and Omar Alcover Firpi

2020 Centering the Classic Maya Kingdom of Sak Tz'i'. Journal of Field Archaeology 45:67-85.

González Cruz, Arnoldo

2011 La reina roja: Una tumba real de Palenque. 1st ed. Consejo Nacional para la Cultura y las Artes, Instituto Nacional de Antropolgía e Historia, Mexico City.

González Cruz, Arnoldo, and Joshua Balcells González

2015 The Funerary Complex of Temple XX: Offering and Ritual in the Early Classic Period of Palenque. In Maya Archaeology, edited by Charles W. Golden, Stephen D. Houston, and Joel Skidmore, pp. 92-115. Precolumbia Mesoweb Press, San Francisco.

Greene Robertson, Merle

2000 Murals Found in Subterranean Tomb of Temple XX, Palenque. Pre-Columbian Art Research Institute Newsletter 25:1-2.

2001 Los murales de la Tumba Del Templo XX Sub de Palenque. In $L a$ pintura mural prehispánica en México, II, Área Maya. Tomo IV, Estudios, edited by Beatriz de la Fuente and Leticia Staines Cicero, pp. 381-388. La pintura mural prehispánica en México, II. Instituto de Investigaciones Estéticas, Universidad Nacional Autónoma de México, Mexico City.

Hare, Timothy, Marilyn Masson, and Bradley Russell

2014 High-Density LiDAR Mapping of the Ancient City of Mayapán. Remote Sensing 6:9064-9085.
Holata, Lukáš, Jindřich Plzák, Radek Světlík, and João Fonte

2018 Integration of Low-Resolution ALS and Ground-Based SfM Photogrammetry Data. A Cost-Effective Approach Providing an 'Enhanced 3D Model' of the Hound Tor Archaeological Landscapes (Dartmoor, South-West England). Remote Sensing 10:1357.

Houston, Stephen D., Sarah E. Newman, Edwin Román, and Thomas G. Garrison

2015 Temple of the Night Sun: A Royal Tomb at EI Diablo, Guatemala. Precolumbia Mesoweb Press, San Francisco.

Inomata, Takeshi, Daniela Triadan, Flory Pinzón, Melissa Burham, José

Luis Ranchos, Kazuo Aoyama, and Tsuyoshi Haraguchi

2018 Archaeological Application of Airborne LiDAR to Examine Social Changes in the Ceibal Region of the Maya Lowlands. PLoS One 13:e0191619.

Inomata, Takeshi, Daniela Triadan, Verónica A. Vázquez López, Juan Carlos Fernandez-Diaz, Takayuki Omori, María Belén Méndez Bauer, Melina García Hernández, Timothy Beach, Clarissa Cagnato, Kazuo Aoyama, and Hiroo Nasu

2020 Monumental Architecture at Aguada Fénix and the Rise of Maya Civilization. Nature 582:530-533.

Inomata, Takeshi, Flory Pinzón, José Luis Ranchos, Tsuyoshi Haraguchi,

Hiroo Nasu, Juan Carlos Fernandez-Diaz, Kazuo Aoyama, and Hitoshi Yonenobu

2017 Archaeological Application of Airborne LiDAR with Object-Based Vegetation Classification and Visualization Techniques at the Lowland Maya Site of Ceibal, Guatemala. Remote Sensing 9:563.

Johnson, Lisa M.

2018 Tracing the Ritual 'Event' at the Classic Maya City of Palenque, Mexico. Unpublished Ph.D. dissertation, Department of Anthropology, University of California, Berkeley.

Kováč, Milan, Alice Desprat, and Carlos Pallán Gayol

2015 New Stucco Masks from Uaxactun: Interpretation, Conservation, and Documentation of Extraordinary Preclassic Maya Art. In Archaeology on Three Continents 2006-2011, edited by Drahoslav Hulínek, Dominik Bonatz, and Milan Kováč, pp. 125-142. Slovak Archaeological and Historical Institute, Bratislava.

Lambers, Karsten, Henri Eisenbeiss, Martin Sauerbier, Denise

Kupferschmidt, Thomas Gaisecker, Soheil Sotoodeh, and Thomas Hanusch

2007 Combining Photogrammetry and Laser Scanning for the Recording and Modelling of the Late Intermediate Period Site of Pinchango Alto, Palpa, Peru. Journal of Archaeological Science 34:1702-1712.

Lercari, Nicola

2016 Terrestrial Laser Scanning in the Age of Sensing. In Digital Methods and Remote Sensing in Archaeology, edited by Maurizio Forte and Stefano Campana, pp. 3-33. Quantitative Methods in the Humanities and Social Sciences. Springer International Publishing, Cham.

2019 Monitoring Earthen Archaeological Heritage Using Multi-Temporal Terrestrial Laser Scanning and Surface Change Detection. Journal of Cultural Heritage 39:152-165.

Lercari, Nicola, Arianna Campiani, and Rodrigo Liendo Stuardo

2018 Intra-site Digital Documentation of the Ancient Maya city of Palenque, Mexico. In 3rd Digital Heritage International Congress (DigitalHERITAGE) Held Jointly with 2018 24th International Conference on Virtual Systems and Multimedia (VSMM 2018), pp. 459-467. IEEE, New York.

Liendo Stuardo, Rodrigo, Javier López Mejía, and Arianna Campiani

2014 The Social Construction of Public Spaces at Palenque and Chinikihá, Mexico. In Mesoamerican Plazas, edited by Tsukamoto Kenichiro and Takeshi Inomata, pp. 108-120. University of Arizona Press, Tucson.

López Jiménez, Fanny

2001 El descubrimiento de la Tumba I del Templo de La Calavera y su contexto arquitectónico en Palenque, Chiapas. Pueblos y Fronteras 1: $115-129$.

Loten, Stanley H., and David M. Pendergast

1984 A Lexicon for Maya Architecture. Archaeological Monograph 8. Royal Ontario Museum, Toronto.

Marken, Damien B.

2007 The Construction Chronology of Palenque: Seriation within an Architectural Form. In Palenque: Recent Investigations at the Classic Maya Center, edited by Damien Marken, pp. 57-84. Altamira Press, New York.

Marken, Damien B., Stanley P. Guenter, and David A. Freidel

2017 He's Maya, but He's Not My Brother: Exploring the Place of Ethnicity in Classic Maya Social Organization. In The Only True People, 
edited by Bethany Beyyette and Lisa LeCount, pp. 187-218. Linking Maya Identities Past and Present. University Press of Colorado, Boulder.

Maudslay, Alfred Percival

1887 Biologia Centrali-Americana, or, Contributions to the Knowledge of the Fauna and Flora of Mexico and Central America, Vol. 4. 6 vols. R.H. Porter and Dulau and Company, London.

Merlo, Alessandro, Andrea Aliperta, and Riccardo Montuori

2017 Strumenti e metodi per la documentazione digitale degli scavi archeologici: La blanca (Petén-Guatemala). Restauro Archeologico 2017:26-47.

Merlo, Alessandro, Eduardo Vendrell-Vidal, Filippo Fantini, and Carlos

Sánchez-Belenguer

2012 The Mayan Mascarón from Chilonché (Petén, Guatemala). In CHNT 17, 2012-Proceedings, p. 16. Museen der Stadt Wien-Stadtarchäologie, Mag.a Karin Fischer Ausserer, Vienna.

Murtha, Timothy M., Eben N. Broadbent, Charles Golden, Andrew Scherer, Whittaker Schroder, Ben Wilkinson, and Angélica Almeyda Zambrano

2019 Drone-Mounted Lidar Survey of Maya Settlement and Landscape. Latin American Antiquity 30:630-636.

Nex, Francesco, and Fulvio Rinaudo

2011 LiDAR or Photogrammetry? Integration Is the Answer. European Journal of Remote Sensing 43:107-121.

O'Driscoll, James

2018 Landscape Applications of Photogrammetry Using Unmanned Aerial Vehicles. Journal of Archaeological Science: Reports 22:32-44.

Olsen, Michael J.

2015 In Situ Change Analysis and Monitoring through Terrestrial Laser Scanning. Journal of Computing in Civil Engineering 29:04014040.

Olsen, Michael J., Falko Kuester, Barbara J. Chang, and Tara C. Hutchinson 2009 Terrestrial Laser Scanning-Based Structural Damage Assessment. Journal of Computing in Civil Engineering 24:264-272.

Opitz, Rachel

2016 Airborne Laserscanning in Archaeology: Maturing Methods and Democratizing Applications. In Digital Methods and Remote Sensing in Archaeology, edited by Maurizio Forte and Stefano Campana, pp. 35-50. Quantitative Methods in the Humanities and Social Sciences. Springer International Publishing, Cham.

Opitz, Rachel, and David Cowley

2012 Interpreting Archaeological Topography: Lasers, 3D Data, Observation, Visualisation and Applications. In Interpreting Archaeological Topography: 3 D Data, Visualisation and Observation, edited by Rachel Opitz and David Cowley, pp. 1-12. Oxbow Books, Barnsley.

Rands, Barbara

1954 Ceramics of the Temple of the Inscriptions, Palenque, Chiapas, Mexico. Master's thesis, Department of Anthropology, University of New Mexico, Albuquerque.

Reese-Taylor, Kathryn, Armando Anaya Hernández, F. C. Atasta Flores Esquivel, Kelly Monteleone, Alejandro Uriarte, Christopher Carr, Helga

Geovannini Acuña, Juan Carlos Fernandez-Diaz, Meaghan

Peuramaki-Brown, and Nicholas Dunning

2016 Boots on the Ground at Yaxnohcah: Ground-Truthing Lidar in a Complex Tropical Landscape. Advances in Archaeological Practice 4:314-338.

Remondino, Fabio, Armin Gruen, Jennifer von Schwerin, Henri Eisenbeiss, Alessandro Rizzi, S. Girardi, Martin Sauerbier, and Heather

Richards-Rissetto

2009 Multi-Sensor 3D Documentation of the Maya Site of Copan. In 22nd CIPA Symposium, pp. 131-136. Electronic document, CIPA Heritage Documentation, https://www.cipaheritagedocumentation.org/activities/ conferences/proceedings_2009.

Richards-Rissetto, Heather, and Kristin Landau

2019 Digitally-Mediated Practices of Geospatial Archaeological Data: Transformation, Integration, and Interpretation. Journal of Computer Applications in Archaeology 2:120-135.

Richards-Rissetto, Heather, Jim Robertsson, Jennifer von Schwerin, Giorgio Agugiaro, Fabio Remondino, and Gabrio Girardi

2013 Geospatial Virtual Heritage: A Gesture-Based 3D GIS to Engage the Public with Ancient Maya Archaeology. In Archaeology in the Digital Era: Papers from the 40th Annual Conference of Computer Applications and Quantitative Methods in Archaeology (CAA), Southampton, 26-29 March 2012, edited by Graeme Earl, Tim Sly, Angeliki Chrysanthi, Patricia Murrieta-Flores, Constantinos Papadopoulos, Iza Romanowska, and David Wheatley, pp. 118-130. Amsterdam University Press, Amsterdam.
Roosevelt, Christopher H., Peter Cobb, Emanuel Moss, Brandon R. Olson, and Sinan Ünlüsoy

2015 Excavation Is Destruction Digitization: Advances in Archaeological Practice. Journal of Field Archaeology 40:325-346.

Ruz Lhuillier, Alberto

1961 Exploraciones Arqueológicas en Palenque: 1957. Anales del INAH, Sexta Época (1939-1966). Anales del INAH 43:35-90.

2005 Costumbres Funerarias de Los Antiguos Mayas. Fondo de Cultura Económica, Mexico City.

2013 El Templo de las Inscripciones: Palenque. 2nd ed. Fondo de Cultura Económica, Mexico City.

Schele, Linda

1986 Architectural Development and Political History at Palenque. In City-States of the Maya. Art and Architecture: A Conference, edited by Elizabeth P. Benson, pp. 110-137. Rocky Mountain Institute for Pre-Columbian Studies, Denver.

Schele, Linda, and Marie Ellen Miller

1992 The Blood of Kings. Dynasty and Ritual in Maya Art. Thames and Hudson, London.

Scherer, Andrew

2012 The Classic Maya Sarcophagus: Veneration and Renewal at Palenque and Tonina. Anthropology and Aesthetics 61-62:242-261.

2018 Grave Matters. Bioarchaeology and Mortuary Archaeology at El Zotz, Bejucal, and El Palmar. In An Inconstant Landscape: The Maya Kingdom of El Zotz, Guatemala, edited by Thomas G. Garrison and Stephen Houston, pp. 303-360. University Press of Colorado, Boulder.

Schneider, Tsim D., and Lee M. Panich

2008 Total Station Mapping: Practical Examples from Alta and Baja California. Journal of California and Great Basin Anthropology 28:166-183.

Smith, Neil G., Luca Passone, Said al-Said, Mohamed al-Farhan, and

Thomas E. Levy

2014 Drones in Archaeology: Integrated Data Capture, Processing, and Dissemination in the al-Ula Valley, Saudi Arabia. Near Eastern Archaeology 77:176-181.

Stuart, David, and George Stuart

2008 Palenque: Eternal City of the Maya. Thames and Hudson, London. Tiesler, Vera, Andrea Cucina, and Arturo Romano Pacheco

2004 Who Was the Red Queen? Identity of the Female Maya Dignitary from the Sarcophagus Tomb of Temple XIII, Palenque, Mexico. Homo: Internationale Zeitschrift fur die vergleichende Forschung am Menschen 55:65-76.

Tokovinine, Alexandre, and Francisco Estrada-Belli

2017 From Stucco to Digital: Topometric Documentation of Classic Maya Façades at Holmul. Digital Applications in Archaeology and Cultural Heritage 6:18-28.

Verhoeven, Geert

2011 Taking Computer Vision Aloft-Archaeological ThreeDimensional Reconstructions from Aerial Photographs with Photoscan. Archaeological Prospection 18:67-73.

Vidal Lorenzo, Cristina, Gaspar Muñoz Cosme, and Alessandro Merlo

2017 Surveying Ancient Maya Buildings in the Forest. In Handbook of Research on Emerging Technologies for Architectural and Archaeological Heritage, edited by Alfonso Ippolito, pp. 255-290. IGI Global, Hershey.

von Schwerin, Jennifer, Heather Richards-Rissetto, Fabio Remondino,

Maria Grazia Spera, Michael Auer, Nicolas Billen, Lukas Loos, Laura

Stelson, and Markus Reindel

2016 Airborne LiDAR Acquisition, Post-Processing and Accuracy-Checking for a 3D WebGIS of Copan, Honduras. Journal of Archaeological Science: Reports 5:85-104.

Vosselman, George, and Hans-Gerd Maas

2010 Airborne and Terrestrial Laser Scanning. CRC Press, Boca Raton. Waagen, Jitte

2019 New Technology and Archaeological Practice. Improving the Primary Archaeological Recording Process in Excavation by Means of UAS Photogrammetry. Journal of Archaeological Science 101:11-20.

Welsh, W. Bruce M.

1988 An Analysis of Classic Lowland Maya Burials. BAR International Series 409. British Archaeological Reports, Oxford.

Wernke, Steven A., Julie A. Adams, and Eli R. Hooten

2014 Capturing Complexity: Toward an Integrated Low-Altitude Photogrammetry and Mobile Geographic Information System Archaeological Registry System. Advances in Archaeological Practice 2:147-163. 